OPEN ACCESS

Edited by:

David Meiri,

Technion - Israel Institute

of Technology, Israel

Reviewed by:

Bruce Bugbee,

Utah State University, United States

Paula Berman,

Weizmann Institute of Science, Israel

${ }^{*}$ Correspondence: Nirit Bernstein

Niri@agri.gov.il

Specialty section:

This article was submitted to Crop and Product Physiology, a section of the journal

Frontiers in Plant Science

Received: 22 January 2021

Accepted: 23 April 2021

Published: 15 July 2021

Citation:

Shiponi S and Bernstein N (2021)

The Highs and Lows of P Supply

in Medical Cannabis: Effects on

Cannabinoids, the lonome

and Morpho-Physiology.

Front. Plant Sci. 12:657323.

doi: 10.3389/fpls.2021.657323

\section{The Highs and Lows of P Supply in Medical Cannabis: Effects on Cannabinoids, the lonome, and Morpho-Physiology}

\author{
Sivan Shiponi ${ }^{1,2}$ and Nirit Bernstein ${ }^{1 *}$ \\ ${ }^{1}$ Institute of Soil Water and Environmental Sciences, Volcani Center, Rishon LeZion, Israel, ${ }^{2}$ The Robert H. Smith Faculty \\ of Agriculture, Food and Environment, The Hebrew University of Jerusalem, Rehovot, Israel
}

Environmental conditions, including the availability of mineral nutrients, affect secondary metabolism in plants. Therefore, growing conditions have significant pharmaceutical and economic importance for Cannabis sativa. Phosphorous is an essential macronutrient that affects central biosynthesis pathways. In this study, we evaluated the hypothesis that $\mathrm{P}$ uptake, distribution and availability in the plant affect the biosynthesis of cannabinoids. Two genotypes of medical "drug-type" cannabis plants were grown under five $\mathrm{P}$ concentrations of $5,15,30,60$, and $90 \mathrm{mg} \mathrm{L}^{-1}$ (ppm) in controlled environmental conditions. The results reveal several dose-dependent effects of $P$ nutrition on the cannabinoid profile of both genotypes, as well as on the ionome and plant functional physiology, thus supporting the hypothesis: (i) $\mathrm{P}$ concentrations $\leq 15 \mathrm{mg} \mathrm{L}^{-1}$ were insufficient to support optimal plant function and reduced photosynthesis, transpiration, stomatal conductance and growth; (ii) $30-90 \mathrm{mg} \mathrm{L}^{-1} \mathrm{P}$ was within the optimal range for plant development and function, and $30 \mathrm{mg} \mathrm{L}^{-1} \mathrm{P}$ was sufficient for producing $80 \%$ of the maximum yield; (iii) lonome: about $80 \%$ of the plant $\mathrm{P}$ accumulated in the unfertilized inflorescences; (iv) Cannabinoids: $P$ supply higher than $5 \mathrm{mg} \mathrm{L}^{-1}$ reduced $\Delta^{9}$-tetrahydrocannabinolic acid (THCA) and cannabidiolic acid (CBDA) concentrations in the inflorescences by up to $25 \%$. Cannabinoid concentrations decreased linearly with increasing yield, consistent with a yield dilution effect, but the total cannabinoid content per plant increased with increasing $P$ supply. These results reveal contrasting trends for effects of $\mathrm{P}$ supply on cannabinoid concentrations that were highest under $<30 \mathrm{mg} \mathrm{L}^{-1} \mathrm{P}$, vs. inflorescence biomass that was highest under $30-90 \mathrm{mg} \mathrm{L}^{-1} \mathrm{P}$. Thus, the $\mathrm{P}$ regime should be adjusted to reflect production goals. The results demonstrate the potential of mineral nutrition to regulate cannabinoid metabolism and optimize pharmacological quality.

Keywords: Cannabis, cannabinoids, development, efficiency, fertilization, nutrition, phosphorus, reproductive

\section{INTRODUCTION}

Cannabis sativa is receiving commercial and academic attention globally due to its therapeutic potential for modern medicine and increasing recreational use (Small, 2018). Recent changes in regulations drive a proliferation of research efforts toward understanding the plant's medical effects (Malfait et al., 2000; Zuardi, 2006; Bonini et al., 2018). The increasing use of cannabis 
as a prescription drug makes understanding the effects of environmental factors and growing conditions on the plant and its chemical composition a high priority (Decorte and Potter, 2015; Saloner and Bernstein, 2021). More than 500 secondary metabolites have been identified in cannabis plants, including terpenoids, flavonoids, and cannabinoids, which are responsible for the therapeutic qualities (Chandra et al., 2017; Gonçalves et al., 2019; Milay et al., 2020).

Secondary metabolites are involved in the interaction of plants with their environment and survival functions, such as attracting pollinators, defense against herbivores and pathogens, plant competition, symbiosis, and responses to environmental stresses (Demain and Fang, 2000; Verpoorte et al., 2002). They have been harnessed for centuries by humanity for use as pharmaceuticals, food additives and flavors (Zhao et al., 2005). These compounds biosynthesis in the plant is regulated by genetic and environmental factors; therefore, elicitation has been used for directing excelled chemical quality (Gorelick and Bernstein, 2014).

Cannabinoids are secondary metabolites produced by cannabis and stored mainly in glandular trichomes on the plant's inflorescences (Turner et al., 1978). More than 100 cannabinoids have been identified in cannabis (Berman et al., 2018; Gülck and Møller, 2020; Milay et al., 2020). The most abundant cannabinoids are the pentyl type $\Delta^{9}$-tetra-hydrocannabinol (THC), cannabidiol (CBD), cannabichromene (CBC), and cannabigerol (CBG) that are present in the plant mostly in their acidic form (THCA, CBDA, CBCA, and CBGA). The precursors for cannabinoid biosynthesis in the cannabis plant are derived from two pathways, the polyketide pathway and the deoxyxylulose phosphate/methyl-erythritol phosphate (DOXP/MEP) pathway (Flores-Sanches and Verpoorte, 2008). CBGA is the direct precursor for THCA, CBDA, and CBCA, and it originates from prenylation of geranyl diphosphate (GPP) to olivetolic acid (Gülck and Møller, 2020). $\Delta^{9}$ tetrahydrocannabivarin (THCV) and cannabidivarin (CBDV), propyl analogs of $\mathrm{THC}$ and $\mathrm{CBD}$, are minor cannabinoids originating from GPP and divarinic acid that have shown important pharmacological activities (Russo, 2011; Bonini et al., 2018; Sarma et al., 2020).

The cannabinoid profile of the plant is dynamic, varies between plants and spatially within the plant (Bernstein et al., 2019a; Danziger and Bernstein, 2021a) and is affected by genetics (Turner et al., 1978; Clarke and Merlin, 2016) and growing conditions (Bernstein et al., 2019b; Danziger and Bernstein, 2021b). Environmental stresses have a potential to be used as management practices to elicit changes in the plant's secondary metabolite profile (Gorelick and Bernstein, 2014, 2017). Abiotic factors such as drought (Caplan et al., 2019), growing media (Caplan et al., 2017), salinity (Yep et al., 2020), light spectrum (Magagnini et al., 2018; Danziger and Bernstein, 2021a), nutrient supply (Bernstein et al., 2019b; Saloner and Bernstein, 2021), and stress elicitors (Jalali et al., 2019) were found to induce changes in the cannabinoid profile of Cannabis sativa plants.

Nutrients are essential for major plant processes such as growth, source-sink relationships, respiration, photosynthesis, photooxidation and metabolites biosynthesis, and involve in regulation and signaling in the plant cell (Engels et al., 2012). Hence, understanding the plant mineral requirements is crucial for improving yield quantity and quality (Wiesler, 2012). Phosphorus is an essential macronutrient and a key element in nucleic acids and phospholipids, as well as in energy transfer processes in the cell. It therefore participates and affects central biosynthesis pathways (White and Hammond, 2008; Shen et al., 2011; Hawkesford et al., 2012). In Arabidopsis plants, $\mathrm{P}$ deprivation reduced the concentrations of 87 primary metabolites, altered the levels of 35 secondary metabolites, and increased most organic acids, amino acids and sugar levels (Pant et al., 2015).

Understanding effects of $\mathrm{P}$ on medical cannabis plants at the reproductive stage is important for regulation of the secondary metabolite profile in the plant material produced for the pharmacology industry. The hypothesis guiding the study was that $\mathrm{P}$ uptake into the plant and its distribution and availability in vegetative and reproductive organs, affect secondary metabolism in cannabis, which is accompanied by changes to the physiological state and the ionome. To test our hypothesis, we exposed the plants to five $\mathrm{P}$ treatments of 5 , $15,30,60$, and $90 \mathrm{mg} \mathrm{L}^{-1}(\mathrm{ppm}) \mathrm{P}$ at the reproductive stage of development, and tested plant development, physiology and chemical profiling of cannabinoids and minerals within the plant. The study was conducted comparatively with two medical cannabis cultivars differing in chemovar to assess genotypic sensitivity to $\mathrm{P}$ nutrition. The obtained results improve our understanding of cannabis plant science, and enable to direct optimization and standardization of the medical product for the benefit of those who need it.

\section{MATERIALS AND METHODS}

\section{Plant Material and Growing Conditions}

Two commercial medicinal cannabis cultivars, "Royal Medic" (RM) and "Desert Queen" (DQ) (Teva Adir Ltd., Israel), representing two chemotypes-(i) high THC and low CBD (DQ) and (ii) balanced THC and CBD (RM)-were chosen for the study. To ensure uniformity between plants, the plants were vegetatively propagated from cuttings of the same mother plant. The rooted cuttings were cultivated under a long photoperiod of 18/6 (day/night) using metal halide bulbs. After 4 weeks, the rooted cuttings, selected for uniformity, were transplanted into 3 -L pots in perlite 2 (1.2) in controlled-environment growing rooms for 10 additional days of vegetative growth under at $25^{\circ} \mathrm{C}$ and $60 \%$ air relative humidity. The plants of each cultivar were divided randomly into five treatment groups of six replicated plants each, and the plants were randomly arranged in the cultivation space. The plants in each group received one of five $\mathrm{P}$ concentrations $\left(5,15,30,60\right.$, and $\left.90 \mathrm{mg} \mathrm{L}^{-1} \mathrm{P}\right)$, and short photoperiod was applied (12/12-h light/dark) using high-pressure sodium bulbs $\left(980 \mu \mathrm{mol} \mathrm{m} \mathrm{m}^{-2} \mathrm{~s}^{-1}\right.$, Greenlab by Hydrogarden, Petah Tikva, Israel) for 63 and 68 days for DQ and $\mathrm{RM}$, respectively. This concentration range was chosen with the goal to target deficiency as well as over-supply of $\mathrm{P}$, for identification of the optimal range of $\mathrm{P}$ supply for physiological 
performance, as well as $\mathrm{P}$ stress response on yield quantity and cannabinoid production. To ensure uniform growing conditions throughout the growing room, light intensity was measured weekly, at every $50 \mathrm{~cm}^{2}$, and adjusted so as not to exceed $10 \%$ variability. The spacing of the plants was $0.2 \mathrm{~m}^{2}$ plant $^{-1}$, and the plants were arranged in the cultivation space such as to minimize overlapping between plants. A reflective aluminum material covered the growing room for maximum reflection and light uniformity. The nutrient solution contained (in $\mathrm{mM}$ ): $10.42 \mathrm{~N}^{-\mathrm{NO}_{3}^{-}}, 2.07 \mathrm{~N}-\mathrm{NH}_{4}^{+}, 2.56 \mathrm{~K}^{+}, 2.99 \mathrm{Ca}^{+2}, 1.44 \mathrm{Mg}^{+2}$, $1.47 \mathrm{~S}_{-} \mathrm{SO}_{4}^{-2}, 0.06 \mathrm{Cl}^{-}, 0.021 \mathrm{Fe}^{+2}, 0.011 \mathrm{Mn}^{+2}, 0.009 \mathrm{~B}^{+3}, 0.005$ $\mathrm{Zn}^{+2}, 0.0008 \mathrm{Cu}^{+2}$, and $0.0003 \mathrm{Mo}^{+2}$. Routine monitoring of the irrigation solution confirmed that the $\mathrm{P}$ concentration remained steady and in accord with the target concentrations; $\mathrm{pH}$ was kept at 5.5-6.0. The leachate solution volume was $\sim 30 \%$ and analyzed weekly for $\mathrm{pH}$ and $\mathrm{P}$ concentration (Supplementary Figure 3). P concentration in the leachate solution of the lowest $\mathrm{P}$ treatment was lower than in the fertigation solution, and under the highest P supply treatments it was higher than in the fertigation solution, and leachate $\mathrm{pH}$ was similar to the $\mathrm{pH}$ of the fertigation solution.

\section{Plant Architecture and Development}

Biomass accumulation was measured at the experiment's termination by destructive samplings. Fresh weight of vegetative organs (leaves, stem, and roots) and reproductive organs (inflorescence and inflorescence leaves) was measured immediately following dissection from the plants. Dry weight (DW) was measured after drying at $65^{\circ} \mathrm{C}$ for $72 \mathrm{~h}$. Morphological parameters (plant height, stem diameter, and the number of nodes on the main stem) were measured once a week throughout the experiment. Stem diameter was measured with a digital caliper (YT-7201, Signet Tools International Co., Ltd., Shengang District, Taiwan) at the location $2 \mathrm{~cm}$ above the plant base. All measurements were conducted on six replicated plants from each treatment in each of the two cultivars tested.

\section{Gas Exchange Parameters (Photosynthesis, Stomatal Conductance, Transpiration Rate, and Intercellular $\mathrm{CO}_{2}$ Concentration)}

A Licor 6400 XT system (LI-COR, Lincoln, NE, United States) was used for the measurements. The youngest mature leaf on the main stem was analyzed $\left[\mathrm{CO}_{2}\right.$ concentration: $400 \mathrm{mg} \mathrm{L}^{-1}$, PPFD: $500 \mu \mathrm{mol}\left(\mathrm{m}^{2} \mathrm{~s}\right)^{-1}$ ]. The leaves' temperature was kept at $25^{\circ} \mathrm{C}$, and the relative humidity at $60 \%$. The measurements were conducted twice during plant development, on day 26 and 54, on six replicated plants for each treatment in each cultivar.

\section{Photosynthetic Pigments}

Five disks, $0.6 \mathrm{~cm}$ in diameter, were removed from the youngest mature fan leaf on the plant main stem after the leaf was washed twice in distilled water and blotted dry. The disks were placed in $0.8 \mathrm{ml} 80 \%(\mathrm{v} / \mathrm{v})$ ethanol and kept in $-20^{\circ} \mathrm{C}$ until further analysis. For the extraction of the pigments from the tissue, the samples were heated to $95^{\circ} \mathrm{C}$ for $30 \mathrm{~min}$, and the solution was collected. Then, $0.5 \mathrm{ml}$ of $80 \%(\mathrm{v} / \mathrm{v})$ ethanol was added to the remaining tissue, and the tubes were heated again for $30 \mathrm{~min}$. The combined extract was mixed by vortex; $0.4 \mathrm{ml}$ was diluted in $5 \mathrm{ml}(\mathrm{v} / \mathrm{v})$ acetone, and absorbance was measured at 663, 664, and $740 \mathrm{~nm}$ by Genesys 10 UV scanning spectrophotometer (Thermo Scientific, Waltham, MA, United States). Chlorophyll $a$ and $b$ and carotenoids were calculated according to Lichtenthaler and Welburn (1983).

\section{Inorganic Mineral Analysis}

At the termination of the experiment, the plants were separated into leaves, stems, roots, inflorescences and inflorescence leaves (that were hand-trimmed from the inflorescences), weighed, rinsed in distilled water, and dried at $65^{\circ} \mathrm{C}$ for $72 \mathrm{~h}$. When dried, the samples were weighed again for dry weight determination, ground, and acid-digested by two different procedures and analyzed for $\mathrm{N}, \mathrm{P}, \mathrm{K}, \mathrm{Ca}, \mathrm{Mg}, \mathrm{Fe}, \mathrm{Zn}$, and $\mathrm{Mn}$ as described in Saloner et al. (2019). The biomass data, the concentration of $\mathrm{P}$ in the various plant organs and total $\mathrm{P}$ in the plant were used for the calculations of $\mathrm{P}$ proportion in specific plant organs (Eq. 1), $\mathrm{P}$ utilization efficiency (Eqs. 2, 3), P acquisition efficiency (Eq. 4), and yield efficiency (Eq. 5).

$$
\begin{aligned}
& P \text { porportion in an organ }=\frac{P \text { in tissue }(m g)}{P \text { in plant }(m g)} \\
& P U E_{t}=\frac{\text { Plant dry weight }(g)}{P \text { in the plant }(m g)} \\
& P U E_{y}=\frac{\text { Inflorescence dry weight }(g)}{P \text { in the plant }(m g)} \\
& P A E=\frac{P \text { in the plant }(m g)}{\text { Root dry weight }(g)}
\end{aligned}
$$$$
\text { Yield efficiency }(\%)=\frac{\text { Inflorescence DW }}{\begin{array}{c}
\text { Treatment that achieved the } \\
\text { highest infloresence DW }
\end{array}} * 100
$$

where $\mathrm{P}$ is phosphorus; PUEt is $\mathrm{P}$ utilization efficiency for total dry weight; $\mathrm{PUE}_{y}$ is $\mathrm{P}$ utilization efficiency for yield dry weight, and PAE is $\mathrm{P}$ acquisition efficiency.

\section{Cannabinoid Analysis}

Cannabinoids were analyzed in inflorescences from two locations in each plant: the apical inflorescence of the main stem (primary inflorescence) and the apical inflorescence of the lowest branch of the main stem (secondary inflorescence). The inflorescences were sampled at the end of the experiment when $\sim 40 \%$ of the trichomes were of amber color. The sampled inflorescences were hand-trimmed and dried in the dark at $19.5^{\circ} \mathrm{C}$ and $45 \%$ air humidity for 2 weeks. The dried samples were crushed

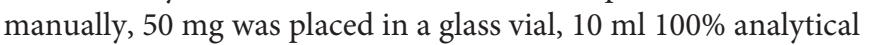
ethanol was added, and the mixture was shaken for $1 \mathrm{~h}$ at room temperature. One milliliter of the extract was filtered through a polyvinylidene difluoride (PVDF) membrane filter of $0.22 \mu \mathrm{m}$ pore size (Bar-Naor Ltd., Ramat Gan, Israel). The cannabinoid concentrations were analyzed using a high-performance liquid chromatography (HPLC) system (Jasco 2000 Plus series) in a spectrum mode. The system consisted of a quaternary 
pump, autosampler, column compartment, and photodiode array (PDA) detector (Jasco, Tokyo, Japan). Chromatographic separations were conducted with a Luna Omega $3 \mu \mathrm{m}$ Polar C18 column (Phenomenex, Torrance, CA, United States), with a length of $150 \mathrm{~mm}$ and internal diameter of $2.1 \mathrm{~mm}$, employing acetonitrile/water $75: 25(\mathrm{v} / \mathrm{v})$ with $0.1 \%(\mathrm{v} / \mathrm{v})$ formic acid, at the isocratic mode, with a flow rate of $1.0 \mathrm{ml} / \mathrm{minute}$ and run time of $20 \mathrm{~min}$ under $25^{\circ} \mathrm{C}$. Quantification was based on analytical standards: $\mathrm{CBC}, \mathrm{CBD}, \mathrm{CBDV}$, cannabichromenic acid (CBCA), cannabidiolic acid (CBDA), cannabidivarinic acid (CBDVA), $\Delta^{9}$-tetrahydrocannabivarinic acid (THCVA), cannabicyclol (CBL), cannabinol (CBN) from Sigma-Aldrich (Germany), cannabicitran (CBT) from Cayman Chemical (Ann Arbor, MI, United States), and THC, $\Delta^{9}$-tetrahydrocannabinolic acid [THCA (THCA-A)], and $\Delta^{9}$-tetrahydrocannabivarin (THCV) from Restek (Bellefonte, PA, United States). For all standards, the linear $R^{2}$ of the calibration curves was $>0.994$ (Saloner and Bernstein, 2021). Concentrations of THCV, CBDV, CBL, $\mathrm{CBN}$, and CBT were lower than the detection limits. The total amount of each cannabinoid in a plant (g/plant) was calculated as the average concentrations of the cannabinoid in the two inflorescences sampled, multiplied by the inflorescence DW yield per plant.

\section{Statistical Analysis}

The data were statistically analyzed by two-way ANOVA, followed by a post hoc Tukey's honest significant difference (HSD) test $(\alpha=0.05)$. Comparison of relevant means was conducted using Fisher's least significant difference test at 5\% level of significance. Pearson correlation was calculated for cannabinoid concentration and yield production. The analysis was performed with the Jump software (Jump package, version 9, SAS 2015, Cary, NC, United States).

\section{RESULTS}

\section{Morphology and Biomass}

$\mathrm{P}$ deficiency inhibited morphological development in both varieties as was apparent by the lower values of all morphological parameters tested under low $\mathrm{P}$ supply (Figure 1). DQ plants were more sensitive to low $\mathrm{P}$ concentration than $\mathrm{RM}$, and growth restriction was apparent in DQ under 5 and $15 \mathrm{mg} \mathrm{L}^{-1} \mathrm{P}$, while in RM growth restriction was greater under $5 \mathrm{mg} \mathrm{L}^{-1}$ compared with $15 \mathrm{mg} \mathrm{L}^{-1} \mathrm{P}$. Phosphorous supply above $30 \mathrm{mg}$ $\mathrm{L}^{-1}$ did not induce further growth stimulation. The elongation rate decreased from the third week of exposure to the short photoperiod and was lowest under $5 \mathrm{mg} \mathrm{L}^{-1} \mathrm{P}$ in both genotypes. Biomass accumulation increased with $\mathrm{P}$ in both cultivars up to $30 \mathrm{mg} \mathrm{L}^{-1} \mathrm{P}$ (Figure 2). Percent $\mathrm{DW}$ of the leaves was highest under $\mathrm{P}$ deficiency in both cultivars. Plants grown under $\mathrm{P}$ deficiency (5-15 $\mathrm{mg} \mathrm{L}^{-1} \mathrm{P}$ ) were smaller than under higher supply rates, with fewer and chlorotic leaves. Furthermore, the inflorescences appeared less dense, and the individual flowers within the inflorescence appeared smaller (Figure 3).

\section{Gas Exchange and Pigments}

Under $\mathrm{P}$ deficiency (5 and $15 \mathrm{mg} \mathrm{L}^{-1} \mathrm{P}$ ), both cultivars had lower rates of photosynthesis, transpiration rate, and stomatal conductance and higher intercellular $\mathrm{CO}_{2}$ concentrations compared with higher supply rates (Figure 4). The measurements were conducted twice during plant development: at the middle and the end of the reproductive growth phase. At late maturation (second measurement), the plants were physiologically less active than earlier in development and had lower stomatal conductance, photosynthesis, and transpiration rates and higher intercellular $\mathrm{CO}_{2}$ (Figure 4). Photosynthesis was highest in both cultivars at the $30-90 \mathrm{mg} \mathrm{L}^{-1} \mathrm{P}$ range, and a small decline above $30 \mathrm{mg}$ $\mathrm{L}^{-1} \mathrm{P}$ was found at the first measurement in DQ (Figures 4A,B). Transpiration rate and stomatal conductance were highest at the first measurement under $30-60 \mathrm{mg} \mathrm{L}^{-1} \mathrm{P}$ in $\mathrm{RM}$ and $30 \mathrm{mg}$ $\mathrm{L}^{-1} \mathrm{P}$ in DQ. At the second measurement, transpiration rate and stomatal conductance were highest at $90 \mathrm{mg} \mathrm{L}^{-1} \mathrm{P}$ in $\mathrm{RM}$ and 60$90 \mathrm{mg} \mathrm{L}^{-1} \mathrm{P}$ in DQ (Figures 4C-F). Intercellular $\mathrm{CO}_{2}$ declined with the increase in $\mathrm{P}$ supply in both measurements; a small rise under 60 and $90 \mathrm{mg} \mathrm{L}^{-1} \mathrm{P}$ was found at the second measurement of RM (Figures 4G,H). The photosynthetic pigments chlorophyll $a$, chlorophyll $b$, and carotenoids increased with the increase in $\mathrm{P}$ application up to $60 \mathrm{mg} \mathrm{L}^{-1}$ and did not change with further increase in $\mathrm{P}$ (Supplementary Figure 1).

\section{Nutrient Accumulation}

The distribution of the nutrients to the plant organs was nutrient specific. $\mathrm{N}, \mathrm{P}$, and $\mathrm{K}$ accumulated to the highest concentrations in the inflorescences. $\mathrm{Ca}$ and $\mathrm{Mg}$ concentrations were highest in the leaves in both cultivars, and high $\mathrm{Mg}$ accumulation was also found in RM inflorescences (Figures 5, 6).

Bioaccumulation of the minerals in the plant's organs was affected by $\mathrm{P}$ supply (Figures 5,6 ). $\mathrm{P}$ concentration in plant tissues increased with $\mathrm{P}$ supply in all plant organs up to $60 \mathrm{mg} \mathrm{L}^{-1}$ (Figures 5A, 6A). Interestingly, $\mathrm{P}$ accumulated in inflorescences to a higher proportion under $\mathrm{P}$ deficiency (Figure 7), and the relative accumulation in the vegetative organs compared to the reproductive tissue increased with the increase in $\mathrm{P}$ availability in the nutrient solution.

In both cultivars, $\mathrm{N}$ concentration in the inflorescences increased with the increase in $\mathrm{P}$ application up to $30 \mathrm{mg} \mathrm{L}^{-1} \mathrm{P}$ (Figures 5B, 6B) but decreased with an increase in $\mathrm{P}$ up to $30 \mathrm{mg}$ $\mathrm{L}^{-1}$ in RM's leaves and stem. $\mathrm{K}$ concentrations in leaves, stem, and root of RM plants and DQ's stem were highest under low $\mathrm{P}$ supply (Figures 5C, 6C). Ca concentration in the root increased with $\mathrm{P}$ supply in both cultivars, unlike the concentrations in the inflorescences and the stem that were highest under $5 \mathrm{mg} \mathrm{L}^{-1} \mathrm{P}$ (Figures 5D, 6D). Leaves' Ca reached a maximum concentration at $30-60 \mathrm{mg} \mathrm{L}^{-1}$ and decreased with further P supply. Like Ca, $\mathrm{Mg}$ concentration in DQ leaves also demonstrated a maximum response curve to $\mathrm{P}$ supply, while in the stem, roots, and inflorescence $\mathrm{Mg}$ concentrations were not affected by the level of P supplied (Figure 6F). However, Mg concentration in RM's stem declined with the increase in $\mathrm{P}, \mathrm{Mg}$ in the leaves increased up to $30 \mathrm{mg} \mathrm{L}^{-1} \mathrm{P}$, and $\mathrm{Mg}$ in the inflorescence increased as well up to $30 \mathrm{mg} \mathrm{L}^{-1} \mathrm{P}$ but decreased with further increase in $\mathrm{P}$ availability. 


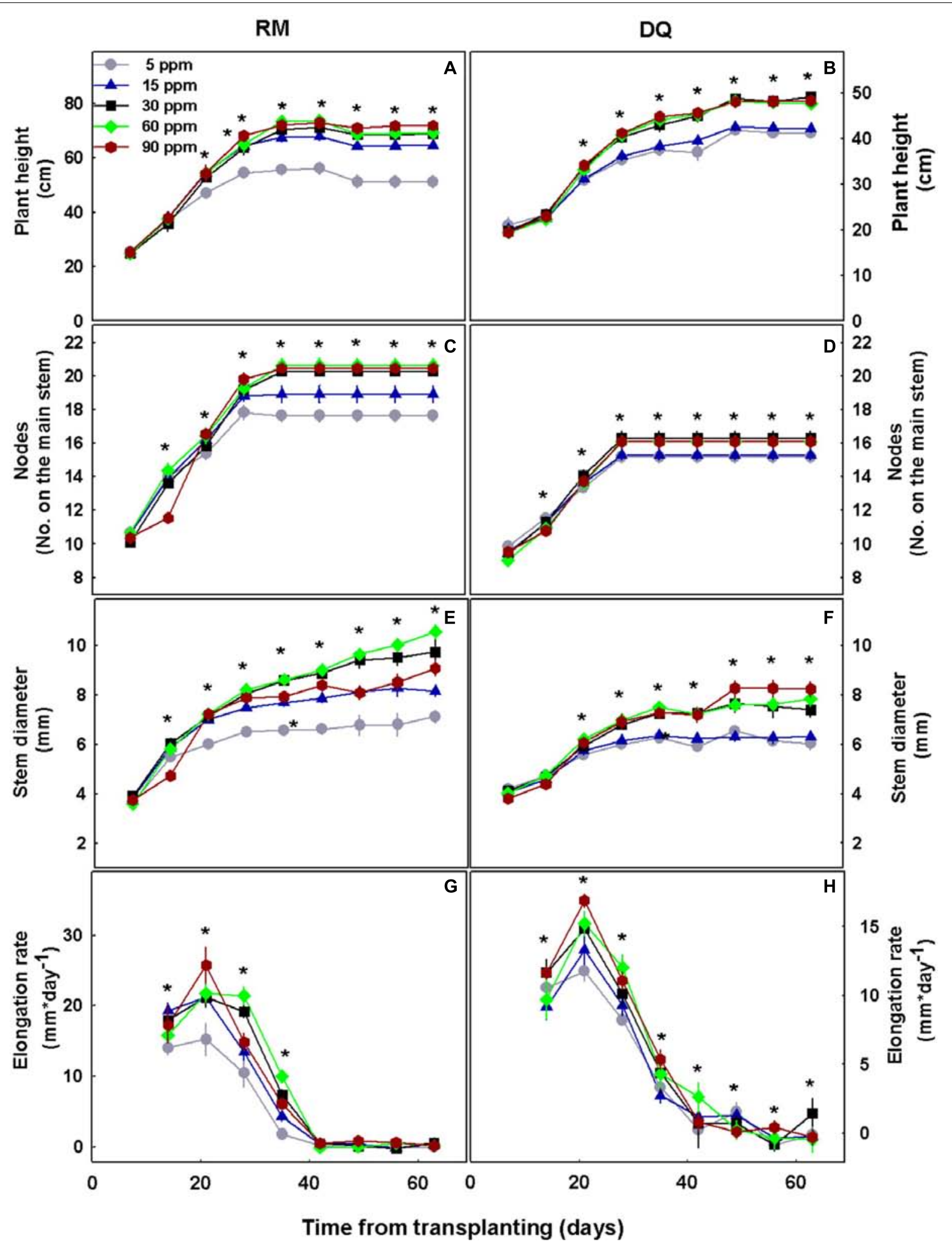

FIGURE 1 | Effect of $P$ concentration on development of two medical cannabis cultivars, $R M$ and $D Q$, at the flowering phase. Plant height (A,B), number of nodes

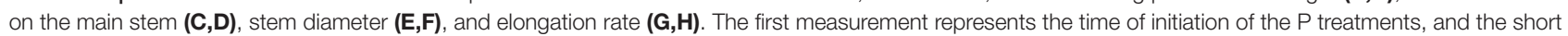
photoperiod. Presented data are averages $\pm \mathrm{SD}(n=6)$. An asterisk above the averages represents a significant difference between treatments for a given day by Tukey's HSD test at $\alpha=0.05$. 


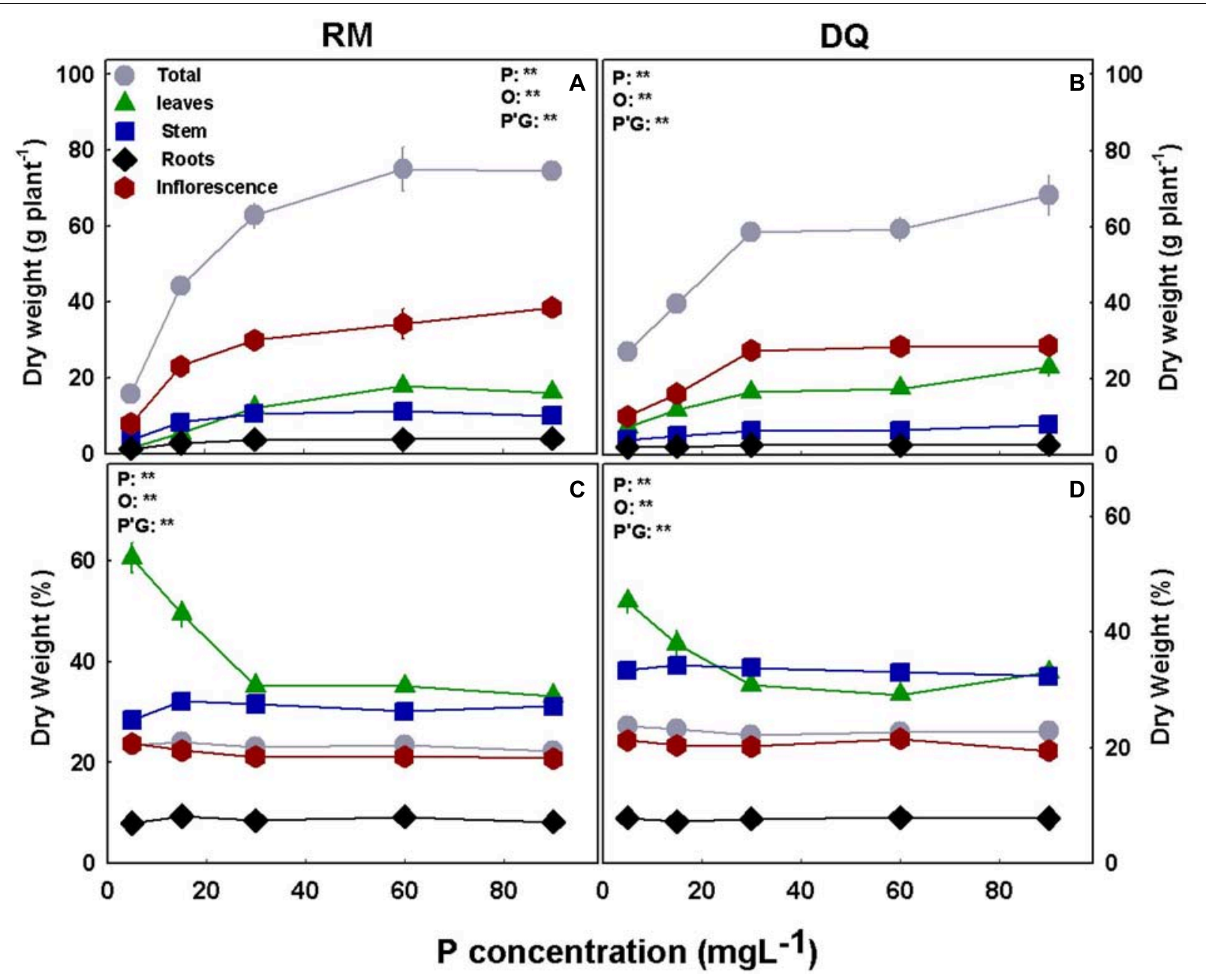

FIGURE 2 | Effect of $\mathrm{P}$ nutrition on biomass of the root and shoot organs in mature medical cannabis plants. Dry weight (A,B) and percentage of dry weight (C,D) of leaves, stems, roots, inflorescences, and total plant of two medical cannabis cultivars, RM (A,C) and DQ (B,D). Presented data are averages \pm SD $(n=6)$. Results of two-way ANOVA indicated as ${ }^{\star \star} P<0.05, F$-test; NS, not significant $P>0.05, F$-test. In the ANOVA results, $P$, phosphorus; $G$, genotype; and $\mathrm{P}^{\star} \mathrm{G}$, the interaction between $P$ and $G$.

Manganese concentration in the leaves presented a maximum response curve to $\mathrm{P}$ supply in $\mathrm{RM}$ and increased with increasing $\mathrm{P}$ up to $30 \mathrm{mg} \mathrm{L}^{-1}$ in DQ (Figures 5F, 6F). In the stem, Mn declined in both cultivars with the increase in P supply, and an increase in RM's stem was found at $90 \mathrm{mg} \mathrm{L}^{-1}$. Mn in the inflorescences was not affected by the treatments in DQ and was highest under $5 \mathrm{mg} \mathrm{L}{ }^{-1} \mathrm{P}$ in $\mathrm{RM}$, demonstrating a genotypic variability in response to $\mathrm{P}$ supply.

Zinc concentration was generally higher in roots and in the inflorescences compared with all other plant organs in both cultivars (Figure 5G, 6G). Zn retention in roots under $\mathrm{P}$ scarcity (5-15 $\mathrm{mg} \mathrm{L}^{-1} \mathrm{P}$ ) was observed in both genotypes. Iron concentration in DQ's leaves was not affected by the treatments and increased with $\mathrm{P}$ in RM (Figures $5 \mathbf{H}, \mathbf{6 H}$ ). In the stem, Fe concentration increased with increasing $\mathrm{P}$ supply up to $30 \mathrm{mg}$ $\mathrm{L}^{-1} \mathrm{P}$ in both cultivars and was higher in DQ. The root's Fe response to the $\mathrm{P}$ treatments was genotype specific; it decreased with $\mathrm{P}$ in $\mathrm{RM}$ and increased in $\mathrm{DQ}$. Inflorescence $\mathrm{Fe}$ was not affected significantly $(P>0.05)$ by the $\mathrm{P}$ treatments besides a slight increase at $90 \mathrm{mg} \mathrm{L}^{-1} \mathrm{P}$ in RM.

\section{P Efficiency}

To assess $\mathrm{P}$ efficiency of the plant, five different parameters were calculated: (i) $\mathrm{PUE}_{t}$ (total $\mathrm{DM} / \mathrm{P}$ ), which analyzes the $\mathrm{DM}$ accumulation per $\mathrm{P}$ in the plant, (ii) $\mathrm{PUE}_{y}$ (flower $\mathrm{DM} / \mathrm{P}$ ), which analyzes the biomass of inflorescence produced per $\mathrm{P}$ in the plant, (iii) PAE (P/root), which calculates the $\mathrm{P}$ taken up by the plant per root unit, (iv) root/shoot ratio, and (v) yield efficiency (inflorescence DW/max inflorescence), which analyzes the percentage of yield in a defined treatment from the maximum yield achieved for the variety (Figure 8). The analyses revealed that $\mathrm{PUE}_{t}$ and $\mathrm{PUE}_{y}$ decline with the increase in $\mathrm{P}$ supply in both cultivars by up to $30 \mathrm{mg} \mathrm{L}^{-1} \mathrm{P}$ and were not affected by a further increase in $\mathrm{P}$ supply (Figures 8A,B).

Phosphorus acquisition efficiency increased with the increase in $\mathrm{P}$ supply in both cultivars by up to $60 \mathrm{mg} \mathrm{L}^{-1} \mathrm{P}$ 


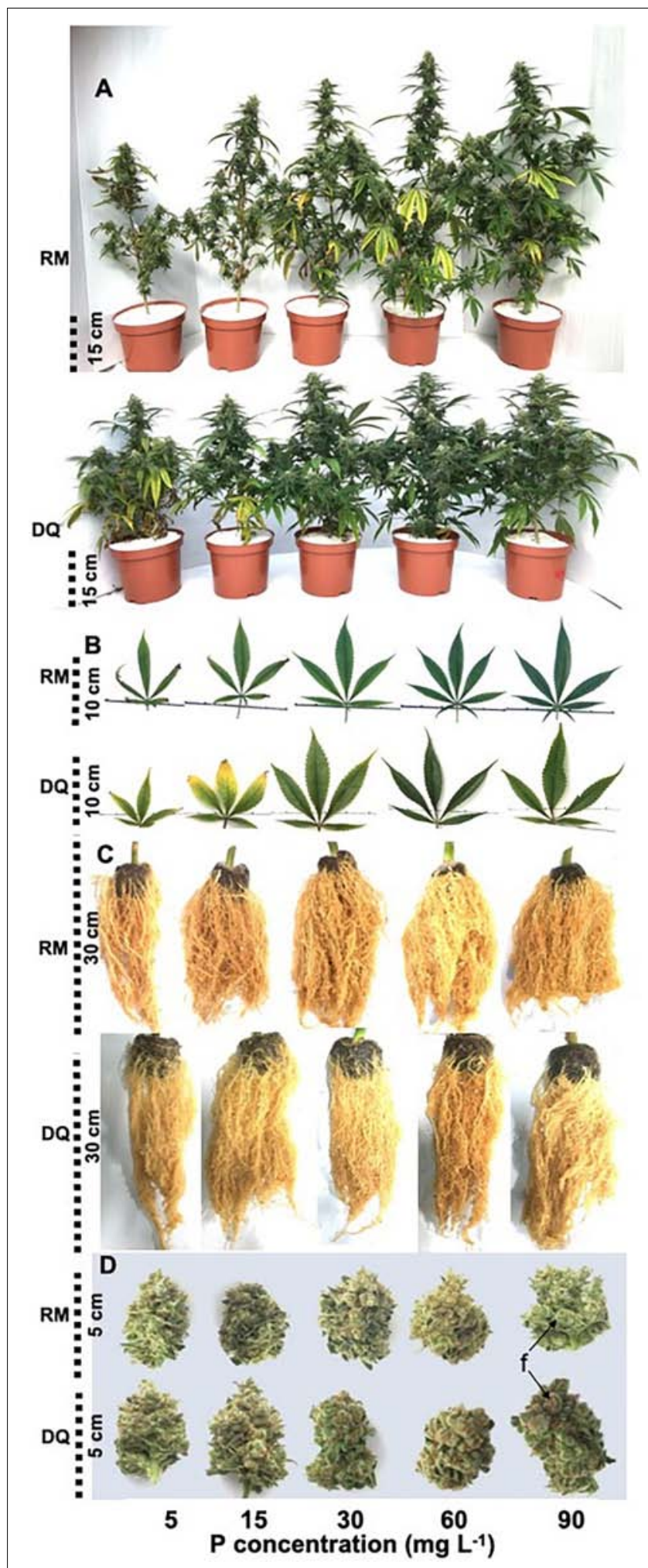

FIGURE 3 | Effect of P supply on visual appearance of whole plants (A), leaves $(\mathbf{B})$, roots $(\mathbf{C})$, and trimmed inflorescences $(\mathbf{D})$ of two medical cannabis cultivars RM and DQ. The images were taken at plant maturity. Shown are the apical inflorescence on the main stem and the youngest fully developed leaf on the main stem. "f" points at individual flowers in the inflorescence.
(Figure 8C). DQ had a higher PAE value than RM. The root/shoot ratio decreased with $\mathrm{P}$ and was significantly higher for RM (Figure 8D). Both cultivars reached $80 \%$ of the maximum yield at $30 \mathrm{mg} \mathrm{L}^{-1} \mathrm{P}$ (Figure $8 \mathrm{E}$ ), yet DQ reached $\sim 20 \%$ higher yield under $30 \mathrm{mg} \mathrm{L}^{-1} \mathrm{P}$ supply.

\section{Cannabinoids}

Cannabinoid concentrations in the inflorescence were affected by the $\mathrm{P}$ treatments and overall reduced with the increase in P supply (Figure 9). THCA and CBDA concentrations had the most profound response to $\mathrm{P}$ concentrations and were reduced with $\mathrm{P}$ supplement in both genotypes and at both locations in the plant (i.e., in the primary and secondary inflorescences) (Figures 9A,B). Despite the considerable effect on THCA and CBDA, THC and CBD did not change significantly and were found at low concentrations (approximately 0.3 and $0.4 \%$ THC and $0.15 \%$ and undetected CBD in RM and DQ, respectively; Supplementary Figure 2). CBDVA was reduced with $\mathrm{P}$ in the primary inflorescence in both genotypes and demonstrated a minimum response curve in the secondary inflorescence (with a minimum at $15-30$ and $30-60 \mathrm{mg} \mathrm{L}^{-1}$ in $\mathrm{RM}$ and DQ, respectively). THCVA concentration was reduced with $\mathrm{P}$ in DQ's secondary inflorescences and in RM in both inflorescences. CBCA was reduced with $\mathrm{P}$ in RM's upper inflorescence and was not affected in DQ. CBC concentration was low in both cultivars (RM: $\sim 0.03 \%$, DQ: $\sim 0.003 \%$ ) (Supplementary Figure 2 ).

The amount of cannabinoids produced per plant increased with $\mathrm{P}$ in RM for all cannabinoids tested (Figure 10). In DQ, such an increase was apparent only up to $30 \mathrm{mg} \mathrm{L}^{-1} \mathrm{P}$ supply.

To understand the link between yield production and the cannabinoid concentrations, Pearson correlation coefficients were tested (Figure 11). In RM, CBDA, THCA, CBDVA, THCVA, and CBCA negatively correlated with yield; THCA and CBDA had the strongest negative correlation. The same results were obtained in DQ, except for CBCA which was not affected by yield in this genotype.

\section{DISCUSSION}

Phosphorus is a constituent of major compounds in the plant cells, such as nucleic acids and phospholipids, and it also plays a central role in energy transformations and as an energy carrier. It is therefore required for many key metabolic processes (Hawkesford et al., 2012). Thereby, the P status of the plant has a strong impact on plant development and metabolism (Wiesler, 2012). The present study evaluated effects of P supply on development and function of medical cannabis plants at the reproductive growth phase and on the profile of cannabinoids, the unique secondary metabolites in cannabis. The results reveal the importance of optimal $\mathrm{P}$ nutrition to the cannabis plant function and morpho-development as secondary metabolism was considerably affected by $\mathrm{P}$ supply as well as the plant gas exchange, $\mathrm{CO}_{2}$ fixation, mineral uptake and translocation, and $\mathrm{P}$ use efficiency. The foremost discovery is the contrasting effect of increasing $\mathrm{P}$ supply to increase inflorescence yield production but to decrease the biosynthesis 


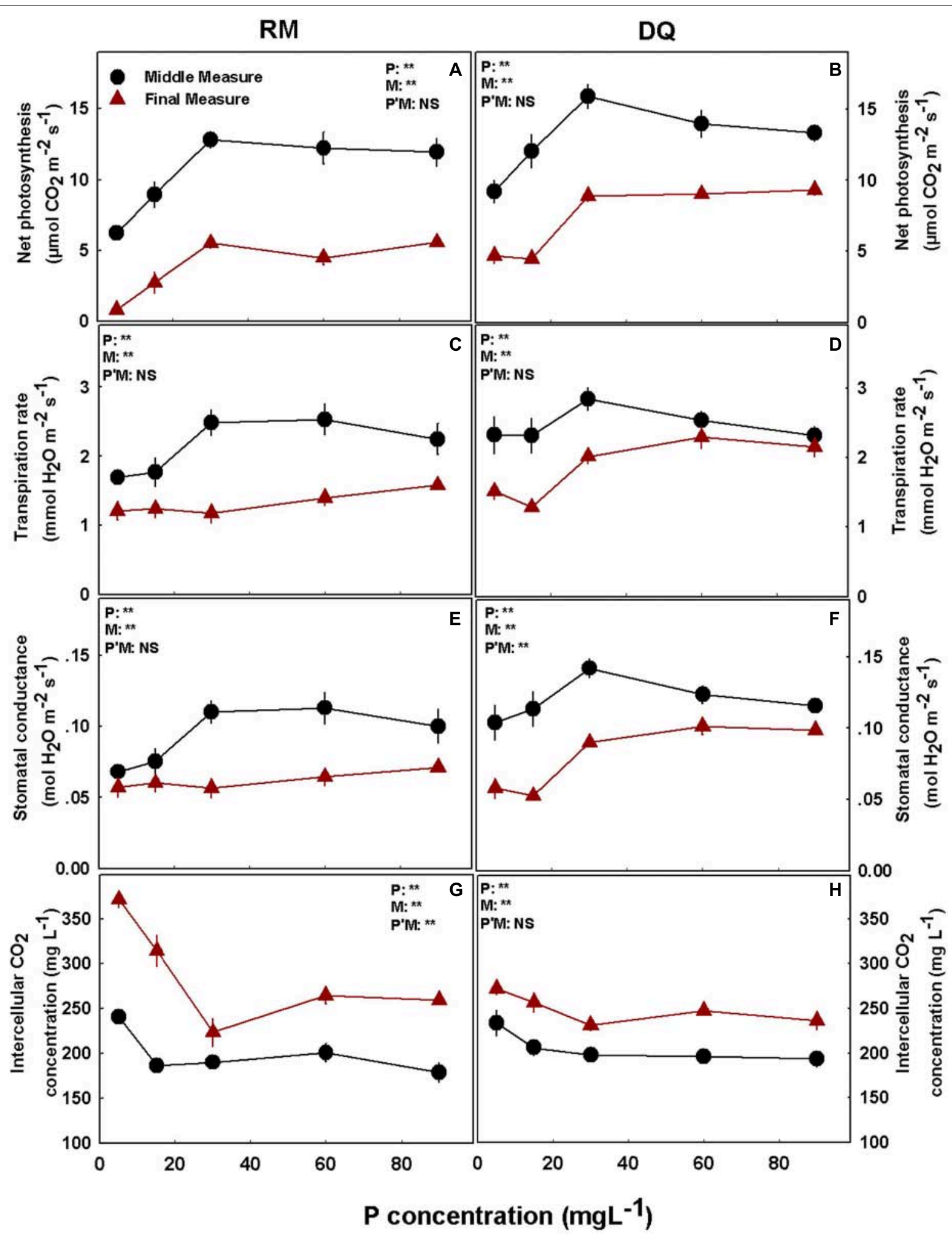

FIGURE 4 | Effect of $\mathrm{P}$ supply on gas exchange parameters in cannabis leaves. Net photosynthesis rate (A,B), transpiration rate $(\mathbf{C}, \mathbf{D})$, stomatal conductance (E,F), and intercellular $\mathrm{CO}_{2} \mathbf{( G , H )}$ for two medical cannabis cultivars, RM and DQ. Results of measurements at two developmental stages, at the middle and at the end of the flowering phase. Presented data are averages $\pm \mathrm{SD}(n=6)$. Results of two-way ANOVA indicated as ${ }^{\star \star} P<0.05, F$-test; NS, not significant $P>0.05, F$-test. In the ANOVA results, $\mathrm{P}^{*} \mathrm{M}$, the interaction between $\mathrm{P}$ and measurement. 


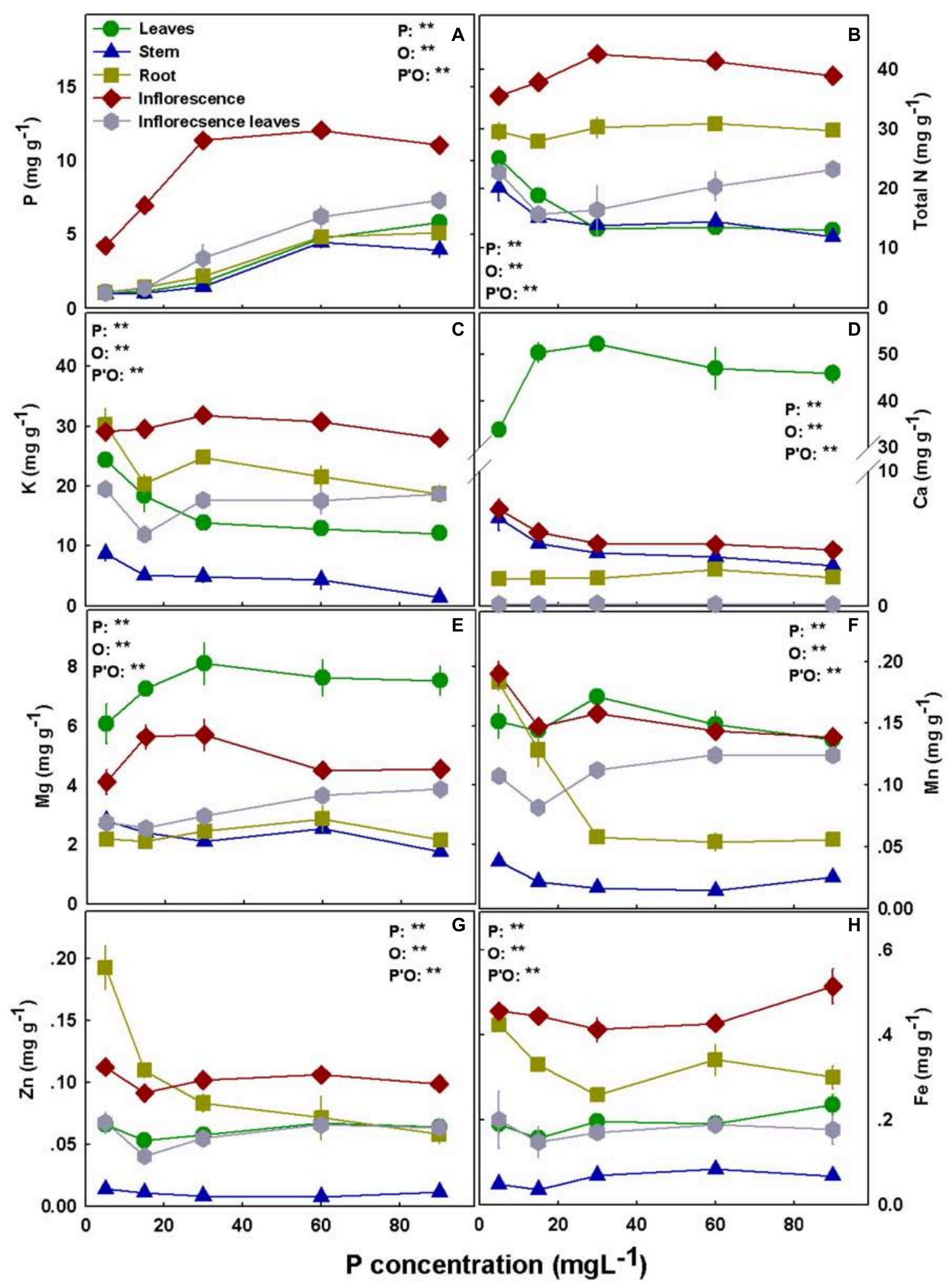

FIGURE 5 | Effect of $P$ supply on nutrient concentrations in leaves, stems, roots, and inflorescences in the medical cannabis cultivar RM. P (A), N (B), K (C), Ca (D), $\mathrm{Mg}(\mathbf{E}), \mathrm{Mn}(\mathbf{F}), \mathrm{Zn}(\mathbf{G})$, and $\mathrm{Fe}(\mathbf{H})$. The presented data are averages $\pm \mathrm{SD}(n=5)$; the concentrations are in $\mathrm{mg} \mathrm{g} \mathrm{DW}^{-1}$. Results of two-way ANOVA indicated as ${ }^{* *} P<0.05, F$-test; NS, not significant $P>0.05, F$-test. In the ANOVA results, $\mathrm{P}$, phosphorus; $\mathrm{O}$, organ; and $\mathrm{P}^{\star} \mathrm{O}$, the interaction between $\mathrm{P}$ and $\mathrm{O}$. 


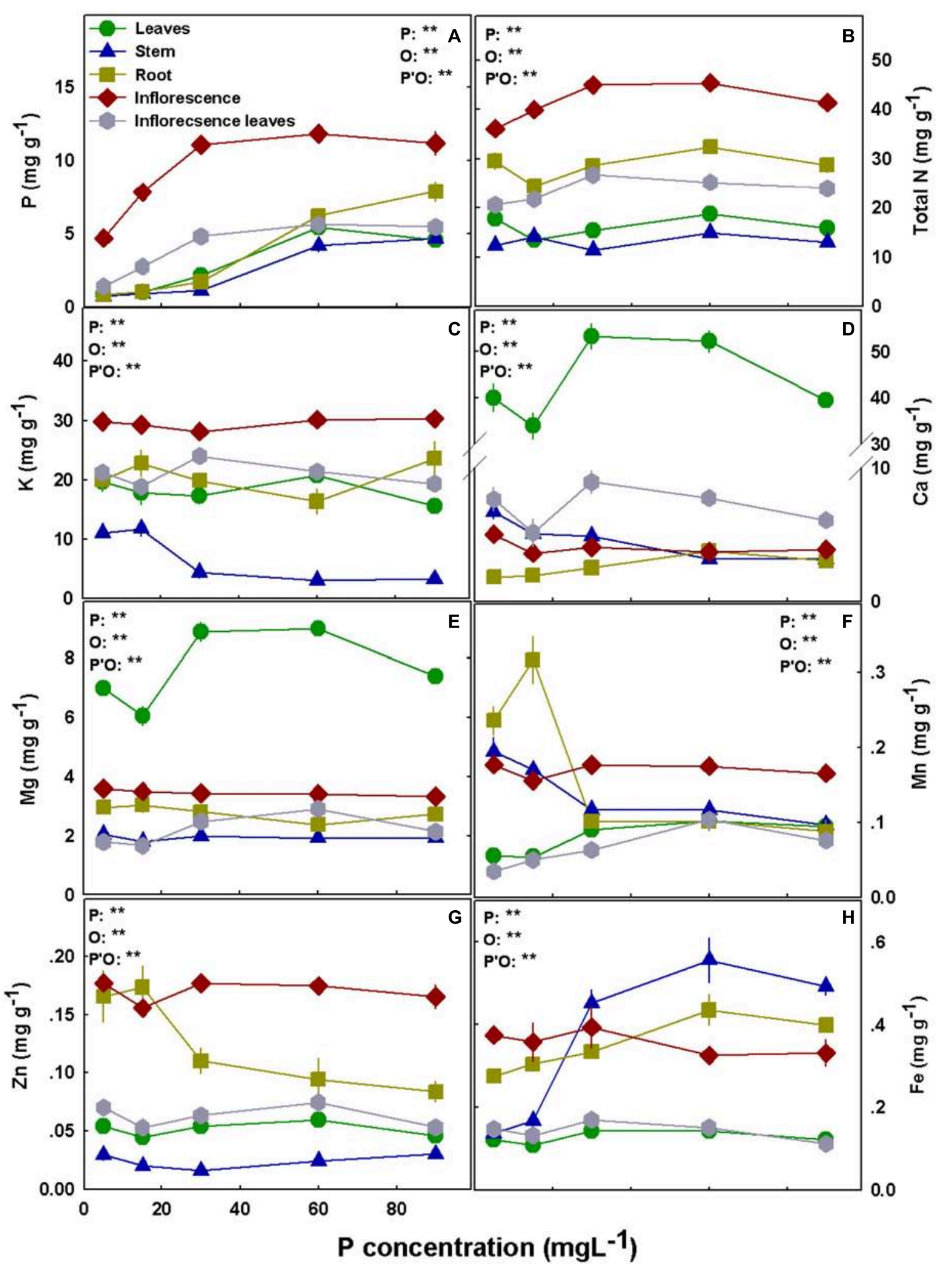

FIGURE 6 | Effect of $P$ supply on nutrient concentrations in leaves, stems, roots and inflorescences in the medical cannabis cultivar DQ. P (A), N (B), K (C), Ca (D), $\mathrm{Mg}(\mathbf{E}), \mathrm{Mn}(\mathbf{F}), \mathrm{Zn}(\mathbf{G})$, and $\mathrm{Fe}(\mathbf{H})$. The presented data are averages $\pm \mathrm{SD}(n=5)$; the concentrations are in $\mathrm{mg} \mathrm{g} \mathrm{DW}^{-1}$. Results of two-way ANOVA indicated as ${ }^{\star \star} \mathrm{P}<0.05, F$-test; NS, not significant $P>0.05, F$-test. In the ANOVA results, $\mathrm{P}$, phosphorus; $\mathrm{O}$, organ; and $\mathrm{P}^{\star} \mathrm{O}$, the interaction between $\mathrm{P}$ and $\mathrm{O}$. 


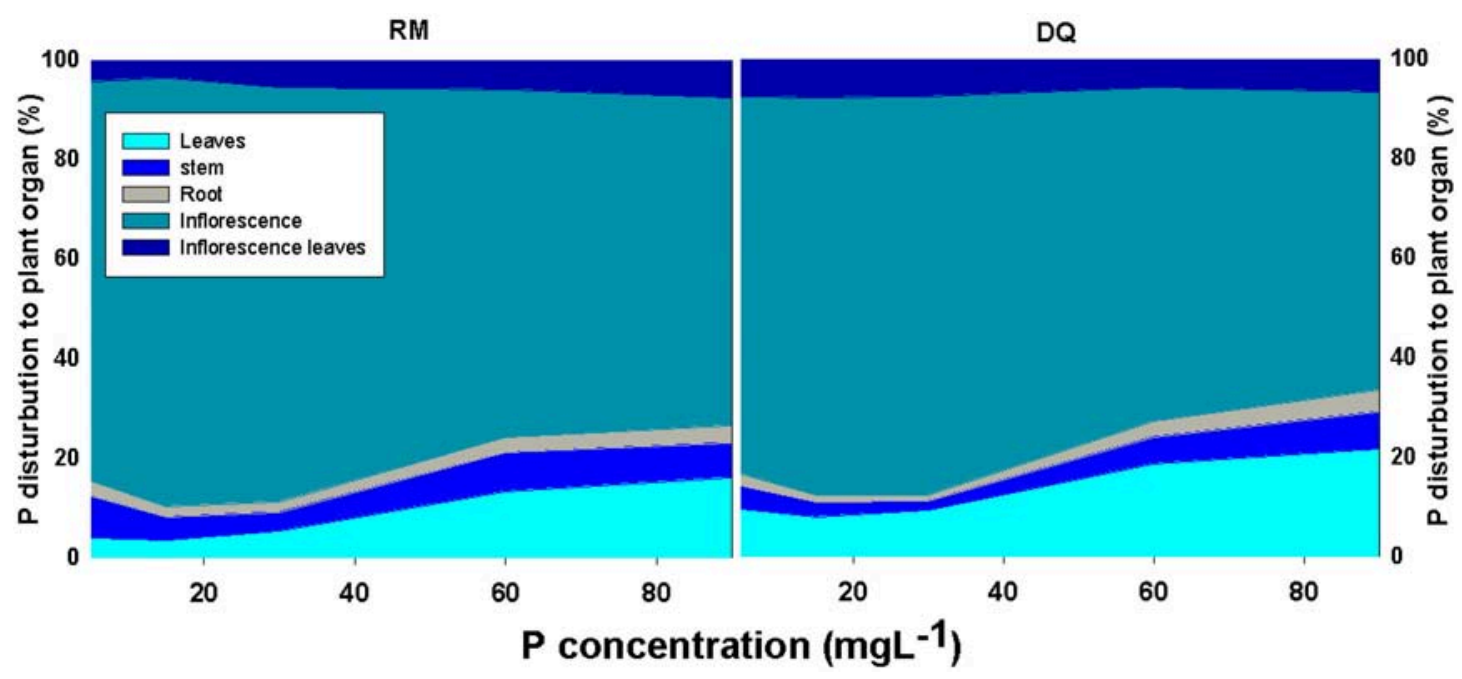

FIGURE 7 | Effect of $\mathrm{P}$ supply on the distribution of $\mathrm{P}$ in the plant to leaves, stem, roots, inflorescences, and inflorescence-leaves, in two medical cannabis cultivars, $\mathrm{RM}$ and $\mathrm{DQ}$. The total $\mathrm{P}$ content in each organ is presented as the percent content of the total $\mathrm{P}$ in the plant. Presented data are averages $(n=5)$.

of major cannabinoids, demonstrating that $\mathrm{P}$ supply needs to be regulated to suit yield quantity vs. chemical quality goals. The revealed influence of $\mathrm{P}$ on the cannabinoid profile can be utilized for adjusting the cannabidiome to achieve a desirable pharmacological profile in the product for medical purposes.

The sensitivity of plant growth and development to P supply at the reproductive phase presented in this study are similar to responses we have recently reported for the vegetative phase (Shiponi and Bernstein, 2021). Responses to $\mathrm{N}$ and $\mathrm{K}$ nutrition are described in Saloner et al. (2019) and Saloner and Bernstein $(2020,2021)$. In both phases of growth, morphological development and biomass deposition are inhibited under $\mathrm{P}$ starvation, and $\mathrm{P}$ concentrations up to $90 \mathrm{mg} \mathrm{L}^{-1} \mathrm{P}$ do not result in toxicity. Additionally, in both phases of plant development, DQ plants are more sensitive to low P than RM plants, demonstrating similar genotypic sensitivity. Similar to our results, stunted growth under $\mathrm{P}$ deficiency was obtained also for hemp, and $\mathrm{P}$ addition above adequate supply did not affect the plant morphology and biomass (Vera et al., 2004, 2010). P toxicity is uncommon in plants because of the plant downregulation mechanisms of P uptake (Dong et al., 1999; Hawkesford et al., 2012).

The effect of $\mathrm{P}$ nutrition on leaf gas exchange parameters was likewise similar for the reproductive (Figure 4) and the vegetative stages (Shiponi and Bernstein, 2021) as well as for the middle and end of the reproductive phase. Photosynthesis, transpiration, and stomatal conductance were lowest under low $\mathrm{P}$ supply and reached a maximum under $30 \mathrm{mg} \mathrm{L}^{-1} \mathrm{P}$ (Figure 4). Inhibition of photosynthesis under $\mathrm{P}$ deficiency was reported for many plants (Brooks, 1986; Wang et al., 2018; Taliman et al., 2019), and the growth restriction we identified under P deficiency could be a result of the lower photosynthesis rate. A decline in photosynthesis, transpiration rate, and stomatal conductance under higher $\mathrm{P}$ application (60 and $90 \mathrm{mg} \mathrm{L}^{-1}$ ) was found only in DQ plants at the first measurement. This resembles results that we have reported previously for the vegetative stage (Shiponi and Bernstein, 2021). Reduced photosynthesis as a result of P toxicity was observed in Hakea prostrata (Shane et al., 2004). However, the reduced photosynthesis under high $\mathrm{P}$ application did not affect DQ's biomass or morphology, demonstrating that carbon fixation was not a limiting factor. $\mathrm{P}$ impact on photosynthesis rate was found to occur via two pathways: by effects on stomatal conductance or by a non-stomatal pathway involving enzymes of the Calvin cycle (Brooks, 1988; Fredeen et al., 1990; Wang et al., 2018). Due to the decrease in photosynthesis rate under low $\mathrm{P}$, intercellular $\mathrm{CO}_{2}$ concentration increased in both cultivars and measurements, likely inducing the reduction in stomatal conductance (Allaway and Mansfield, 1967). The reduction in photosynthesis rate, together with the increase in intercellular $\mathrm{CO}_{2}$ concentration, suggests a non-stomatal restriction on $\mathrm{CO}_{2}$ assimilation under $\mathrm{P}$ deficiency. This result is unlike the response at the vegetative growth stage of medicinal cannabis, where a decrease in intercellular $\mathrm{CO}_{2}$ concentration was found under low P. The reduced chlorophyll concentration under $\mathrm{P}$ deficiency (Supplementary Figure 1) could have contributed to the observed restriction of photosynthetic activity. P starvation has been reported to decrease chlorophyll concentration and photosynthesis in other plants as well (Soltangheisi et al., 2013; Frydenvang et al., 2015). The decline in photosynthesis rate, transpiration rate, and stomatal conductance with plant aging at the reproductive growth phase is probably due to the phenologically induced reduction in growth rates or the beginning of senescence at the end of the experiment that was demonstrated to occur in other plants as well (Tang et al., 2005).

\section{Phosphorus Accumulation, Distribution, and Efficiency}

Phosphorus concentration increased with the increase in $\mathrm{P}$ supply in all plant organs (Figures 5A, 6A). In the leaves, 


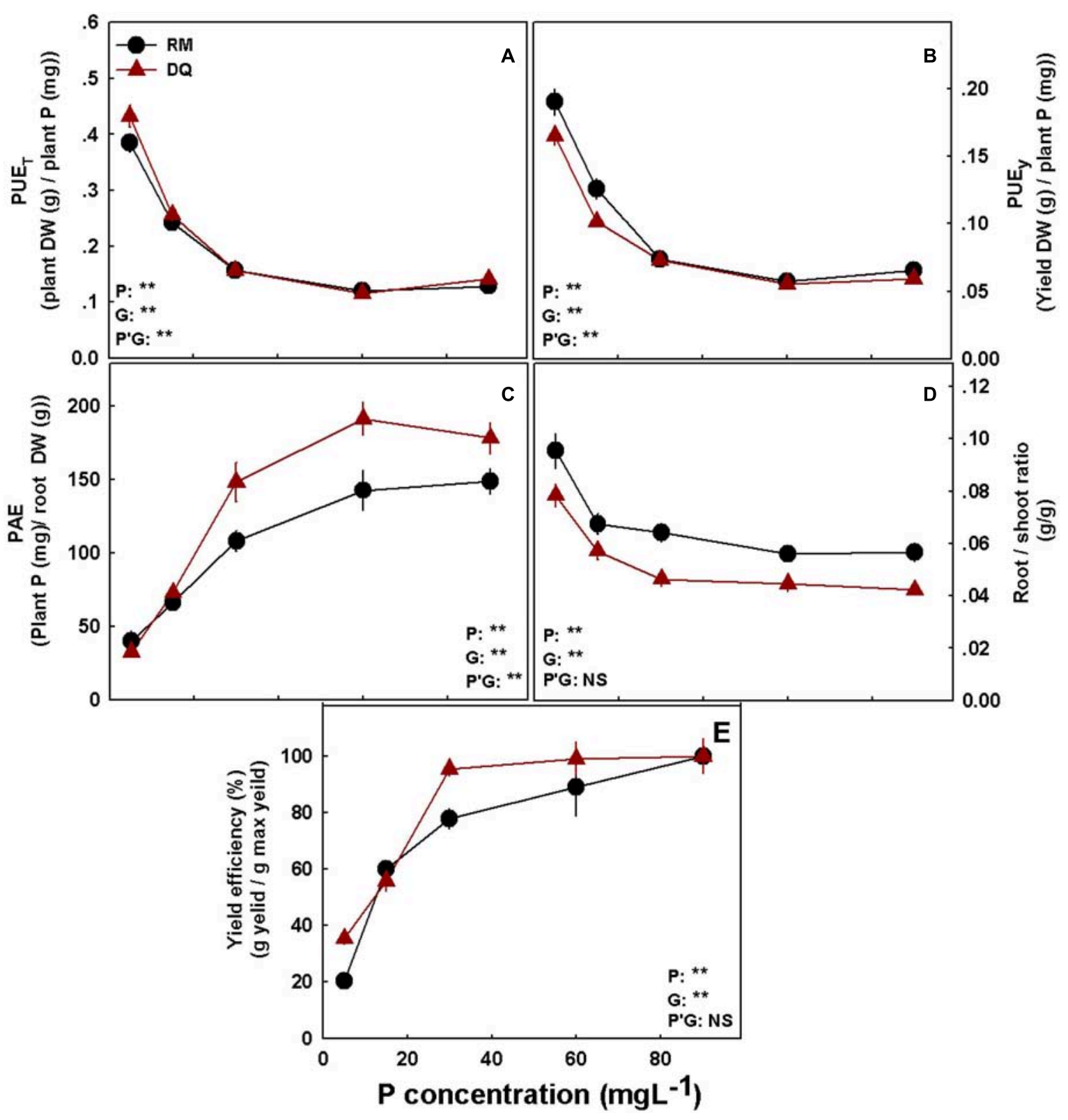

FIGURE 8 | Phosphorus efficiency parameters for two medical cannabis cultivars RM (A) and DQ (B). P utilization efficiency for total dry weight (A), P utilization efficiency for yield dry weight (B), phosphorus acquisition efficiency (C), Root/shoot ratio (D), and yield efficiency (E). Presented data are averages \pm SD $(n=5)$. Results of two-way ANOVA indicated as ${ }^{\star *} P<0.05, F$-test; NS, not significant $P>0.05, F$-test. In the ANOVA results, $P^{*} G$, the interaction between $P$ and genotype.

P concentration reached sufficient levels of $4.0-5.5 \mathrm{mg} \mathrm{g}^{-1}$ under $60 \mathrm{mg} \mathrm{L}^{-1} \mathrm{P}$ supply, in accord with previous results for hemp (5-6 $\mathrm{mg} \mathrm{g}^{-1}$; Iványi and Izsáki, 2009) and for medical cannabis at the vegetative growth stage $\left(3-4 \mathrm{mg} \mathrm{g}^{-1}\right.$; Shiponi and Bernstein, 2021). The leaves in P-"hungry" plants (from the 5 and $15 \mathrm{mg} \mathrm{L}^{-1}$ treatments) and leaves grown under $30 \mathrm{mg} \mathrm{L}^{-1} \mathrm{P}$ supply contained only $\sim 20$ and $\sim 40 \%$ of the P stored in leaves grown under sufficient $P$ nutrition of $60 \mathrm{mg}$ $\mathrm{L}^{-1} \mathrm{P}$, respectively, in both cultivars. Phosphorous levels in the leaves indicate that $60 \mathrm{mg} \mathrm{L}^{-1} \mathrm{P}$ is the optimal application sufficient to support the maximum plant uptake potential. Yet, since plant uptake and accumulation potential do not necessarily support optimal plant function, additional parameters were considered, such as plant development and physiology and secondary metabolite production.

Phosphorus accumulation at the reproductive stage was substantially higher in the inflorescence than in all other plant organs, while at the vegetative growth stage, the highest accumulation was found in the roots (Shiponi and Bernstein, 2021). When biomass is taken into account, the inflorescences contained $\sim 80 \%$ of all plant $\mathrm{P}$ (Figure 7 ). An increase in $\mathrm{P}$ concentration in the nutrient solution decreased the proportion 


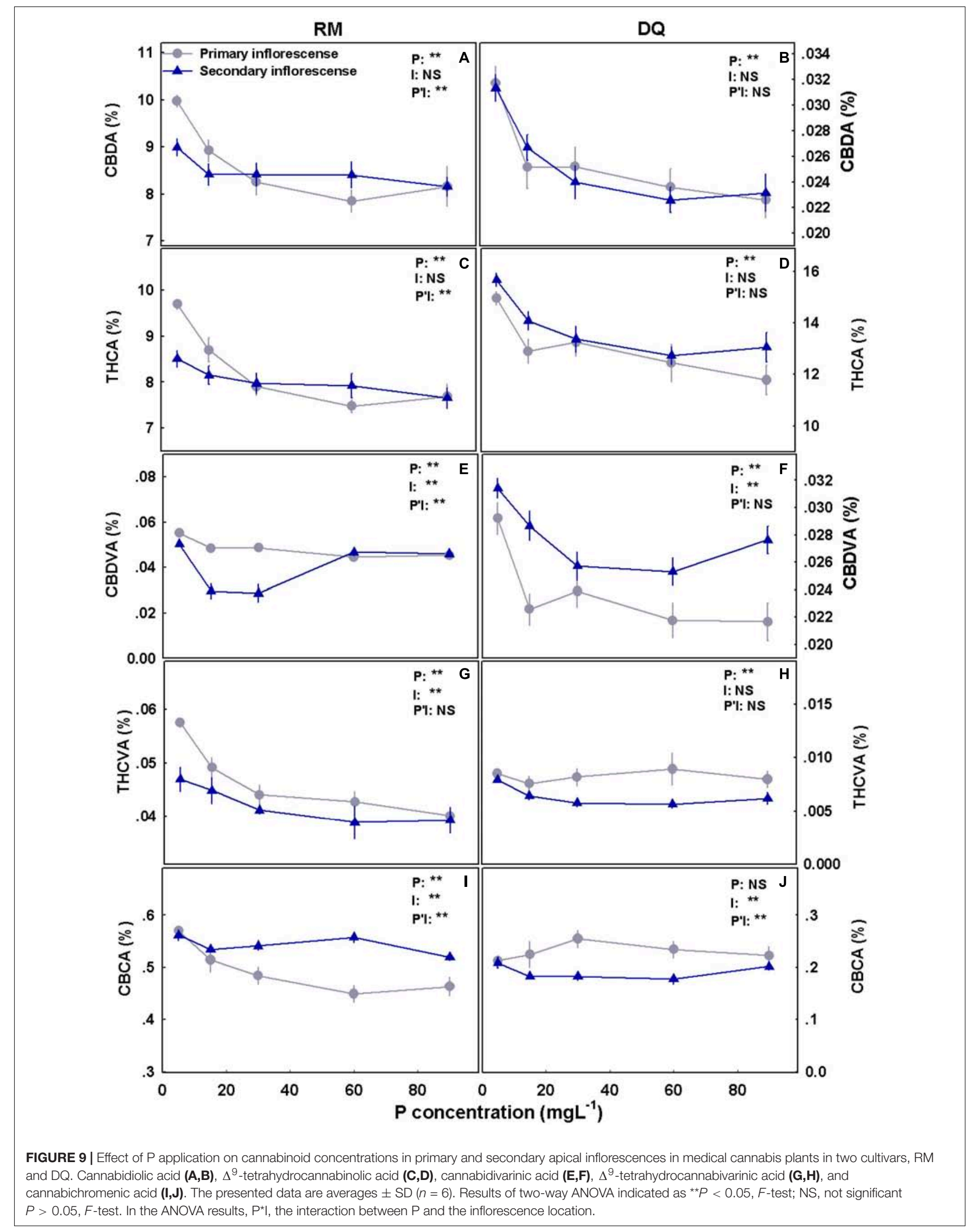




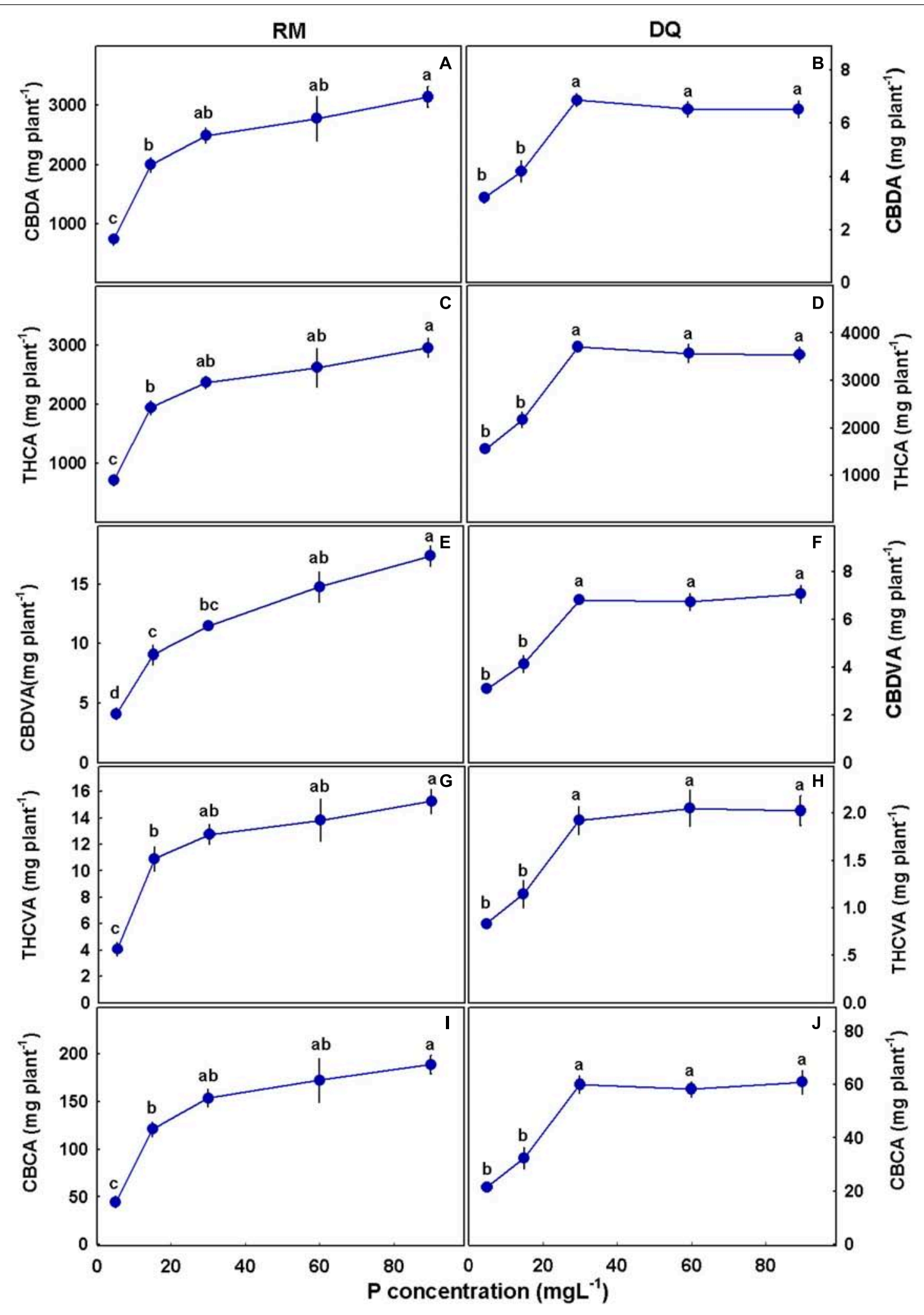

FIGURE 10 | Effect of $\mathrm{P}$ application on cannabinoid yield per plant for two medical cannabis cultivars, RM and DQ. Cannabidiolic acid $(\mathbf{A}, \mathbf{B})$,

$\Delta^{9}$-tetrahydrocannabinolic acid (C,D), cannabidivarinic acid (E, F), $\Delta^{9}$-tetrahydrocannabivarinic acid $(\mathbf{G}, \mathbf{H})$, and cannabichromenic acid $(\mathbf{I}, \mathbf{J})$. The presented data are averages $\pm \mathrm{SD}(n=6)$. Different letters above the means represent significant differences according to Tukey's honest significant difference test at $\alpha=0.05$. 


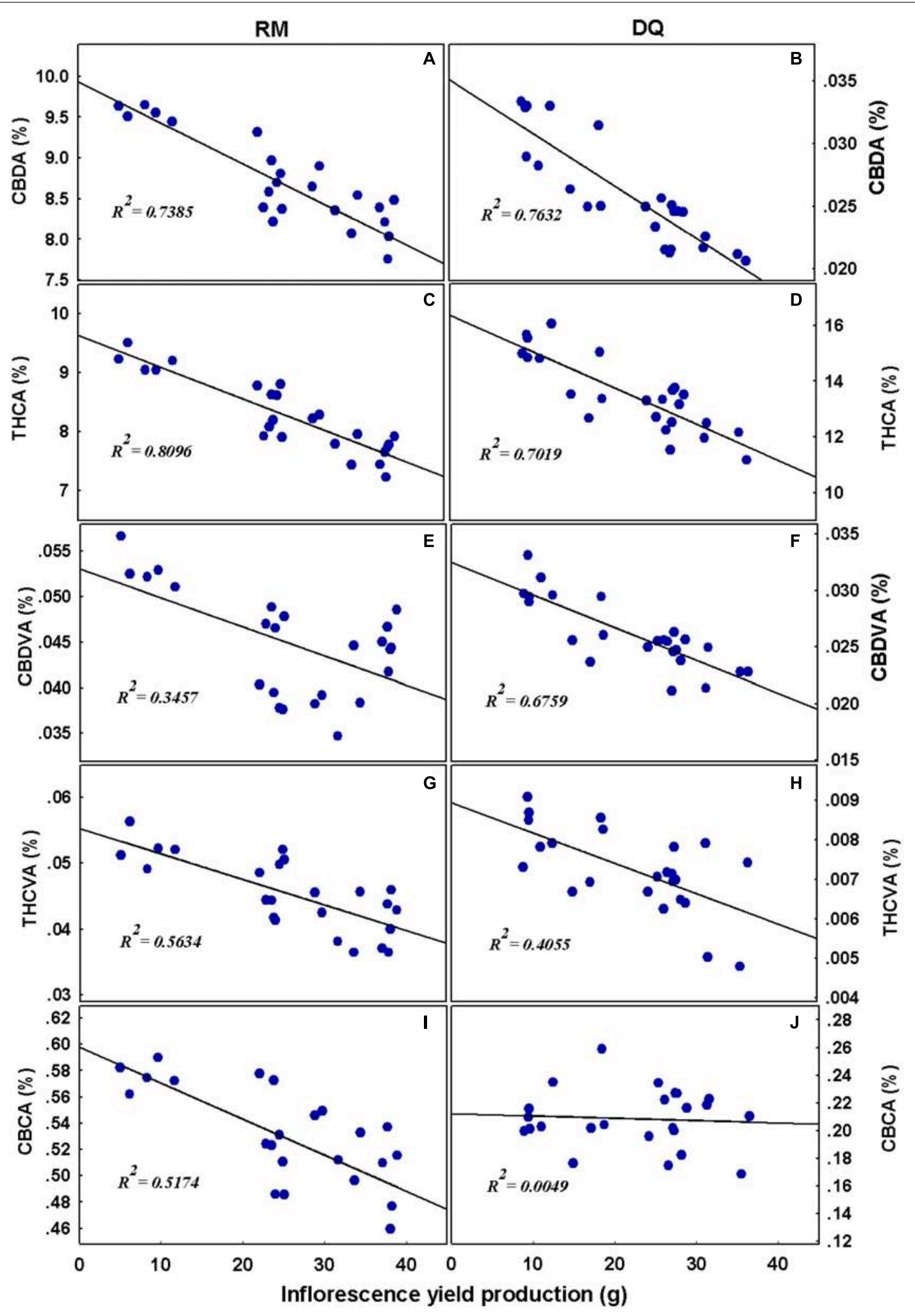

FIGURE 11 | Linear regression analysis. Relationships between cannabinoid concentrations and inflorescence yield per plant. Cannabidiolic acid (A,B), $\Delta^{9}$-tetrahydrocannabinolic acid (C,D), cannabidivarinic acid (E,F), $\Delta^{9}$-tetrahydrocannabivarinic acid $(\mathbf{G}, \mathbf{H})$, and cannabichromenic acid $(\mathbf{I}, \mathbf{J})$. The continuous line represents the linear fit to the data. 
of $\mathrm{P}$ accumulated in the inflorescences on account of an increased proportion of $\mathrm{P}$ at the vegetative tissues. Unlike the results obtained by Snapp and Lynch (1996) for beans, retention of P in roots was not apparent at the reproductive stage, and a higher proportion of $\mathrm{P}$ compartmentation in the root under low $\mathrm{P}$ was not found (Figures 5-7). In line with the results we obtained for cannabis at the vegetative and reproductive stages, a decline in root $\mathrm{P}$ concentration at maturity was found by Rose et al. (2008) for canola under high and adequate P. The enhanced translocation to the inflorescences is likely a result of breeding for excelled flower yield biomass. The reduction of the proportion of $\mathrm{P}$ content in the vegetative tissues under low $\mathrm{P}$ may imply a remobilization of $\mathrm{P}$ to the reproductive organs.

Distribution of minerals to plant organs is known to change with plant development, and the massive translocation of minerals to the reproductive organs supports growth of the next generation (Snapp and Lynch, 1996; Veneklaas et al., 2012). At maturity, $\mathrm{P}$ concentration is typically lower at the vegetative tissues compared to the grains as was found for numerous plants including lupine (Hocking and Pate, 1978), beans (Snapp and Lynch, 1996), wheat (Rose et al., 2007), canola (Rose et al., 2008), and rice (Rose et al., 2010). At the vegetative stage, root uptake is usually a more important source of $\mathrm{P}$ than remobilization between plant tissues. During the reproductive stage, remobilization can become a significant source for support of the new growth (Veneklaas et al., 2012). The results we obtained for cannabis suggest that uptake of $\mathrm{P}$ had an important role in $\mathrm{P}$ supply to the reproductive tissues since the accumulation of $\mathrm{P}$ increased with the increase in $\mathrm{P}$ supply. However, at the termination of the exponential growth spurt that the cannabis plant undergoes at the beginning of the reproductive phase, uptake was reduced, and remobilization played a more important role in inflorescence growth. Significant $P$ uptake may occur postanthesis and was suggested to be genetically related (Rose et al., 2007). Plants re-translocate at least $50 \%$ of the $P$ contained in senescing leaves (Aerts, 1996). Remobilization of $P$ was suggested to be part of the senescence process and pod filling in beans (Grabau et al., 1986; Snapp and Lynch, 1996), and in petunia, at the onset of flowering, the concentration of $\mathrm{P}$ in the vegetative organs decreased, while in the reproductive organ it gradually increased to a maximum concentration at the senescence stage (Zhang et al., 2012). P distribution in medical cannabis at the end of the cultivated plant life cycle as observed in the current study is in accord with previous knowledge on $\mathrm{P}$ accumulation in reproductive organs.

Phosphorus concentration in the inflorescence increased with the increase in $\mathrm{P}$ input up to $30 \mathrm{mg} \mathrm{L}^{-1} \mathrm{P}$ and was not affected by further supply (Figures $5, \mathbf{6}$ ). Taken together with retention in roots under $90 \mathrm{mg} \mathrm{L}^{-1} \mathrm{P}$ in $\mathrm{DQ}$, the lack of increase in $\mathrm{P}$ accumulation in the inflorescences under higher $\mathrm{P}$ supply could be an indication of a defense mechanism against $\mathrm{P}$ toxicity. Phosphorus homeostasis is achieved by many cellular activities, among which are metabolic processes, translocation between tissues, interaction between ions, and membrane transport (Mimura, 1999). In order to maintain cellular P homeostasis, the plant coordinates between various phosphate transporters (Liu et al., 2016). For example, transporters of the PHT1 family are involved in Pi uptake and remobilization and are controlled by a complex regulation network. They are expressed in the roots for Pi uptake from the growing media and are also detected in various shoot organs such as leaves and flowers (Nussaume et al., 2011). Other phosphate transporters take part in organelle Pi transport, energy metabolism, or stress response (Liu et al., 2016). No information is so far available about $\mathrm{P}$ transporters in C. sativa, and this information is needed to shed light on $\mathrm{P}$ remobilization and translocation in the cannabis plant in light of the high $\mathrm{P}$ requirements of the plant. The vacuole functions as a primary compartment for Pi storage and remobilization and buffers Pi concentration in the cytoplasm against fluctuation. Under P deficiency, the Pi pool of the vacuole depletes, and when the Pi storage in the vacuole empties, growth ceases (Bieleski, 1973). Resupply of Pi to Pi-deficient plants results in a rapid flux of Pi into the vacuole. Compartmentation of $\mathrm{Pi}$ in the vacuole has an important role in Pi regulation under Pi starvation that prevents toxic levels of Pi in the cytoplasm under excess P (Liu et al., 2016). The tight Pi regulation within the cell may be the reason for the lack of visible toxicity symptoms in the current experiment.

$P$ efficiency in the plant is gained by phosphorus utilization efficiency (PUE) and phosphorus acquisition efficiency (PAE) (Föhse et al., 1988; Wang et al., 2010a; Veneklaas et al., 2012; $\mathrm{Wu}$ et al., 2013). PAE is a measure of the ability of the root system to obtain P from the soil, and is an integration of many factors including root morphology and architecture, shoot/root ratio, chemical and biological conditions in the rhizosphere, and the type and density of root Pi transporters (Clarkson and Hanson, 1980; White and Hammond, 2008; George et al., 2012). PUE measures the internal P-use requirement and is commonly calculated as DM production to $\mathrm{P}$ concentration in the tissue (Balemi and Schenk, 2009b). PAE is frequently estimated as total P uptake/root biomass (Clarkson and Hanson, 1980). To estimate the external $\mathrm{P}$ requirement for optimal yield production by the cannabis plants, we calculated yield efficiency for each treatment as the percentage of yield achieved compared with the maximum yield produced. Based on previous studies, $80 \%$ of the maximum yield was defined as the threshold for the optimal P requirement (Föhse et al., 1988; Gourley et al., 1993). Both genotypes had a similar PUE response for the production of total DM and yield (Figures 8A,B). As described by Batten (1992), PUE in wheat was higher under $\mathrm{P}$ deficiency. Similar results were obtained for potato (Balemi and Schenk, 2009b), cotton (Wang et al., 2018), and lettuce (Neocleous and Savvas, 2019). $\mathrm{PUE}_{t}$ under low $\mathrm{P}$ supplement was significantly higher for $\mathrm{DQ}$, but $\mathrm{PUE}_{y}$ was higher for RM (Figures 8A,B). Hence, in RM, utilization of $\mathrm{P}$ under deficiency is directed more toward reproductive growth than in DQ.

Phosphorus acquisition efficiency increased with $\mathrm{P}$ supply and was higher for DQ compared with RM under adequate P nutrition (30-90 $\mathrm{m} \mathrm{L}^{-1}$ ) (Figure 8C). Although root/shoot ratio was higher for RM, DQ's PAE was higher, which indicates that, in this variety, parameters other than root/shoot ratio played an important part in $\mathrm{P}$ acquisition. Among the required traits for efficient $\mathrm{P}$ acquisition by plants are root elongation, increased root/shoot ratio, proliferation of root hairs and lateral roots, root secretion that affects chemical and electrochemical properties in 
the rhizosphere, and membrane transport properties (White and Hammond, 2008; Wang et al., 2010a). As expected, root/shoot ratio decreased with the increase in $\mathrm{P}$ supply in both varieties (Figure 8D). Amplified root/shoot ratio under P scarcity is well known as a defense mechanism to promote $\mathrm{P}$ uptake (Bieleski, 1973; Shen et al., 2011; Hawkesford et al., 2012).

Wang et al. (2010a) have suggested that the plant's $P$ efficiency depends mainly on genetic factors. Genetic variation in P efficiency was found in wheat (Ozturk et al., 2005), potato (Balemi and Schenk, 2009a), cotton (Wang et al., 2018), lettuce (Neocleous and Savvas, 2019), and soybean (Wang et al., 2010a,b). Overall, minor variations in PUE were found between the cannabis varieties tested, and PAE was significantly higher for DQ than RM.

The external requirement of $\mathrm{P}$ to achieve $80 \%$ of the maximum yield in both varieties was $30 \mathrm{mg} \mathrm{L}^{-1}$ (Figure 8E). The data presented here suggest that to achieve maximum yield, a minimum supply of $30 \mathrm{mg} \mathrm{L}^{-1} \mathrm{P}$, and an optimum $\mathrm{P}$ supply range of $30-90 \mathrm{mg} \mathrm{L}^{-1} \mathrm{P}$, are required in both cultivars.

\section{Interplay Between P Nutrition and the Cannabis Plant lonome}

Plants require minerals for growth and development. Macroelements that are present at high concentrations in the plant as well as microelements that are accumulated at considerably lower concentrations are essential for plant function and survival (Kirkby, 2012). Interactions between minerals can affect root uptake and in planta translocation. Ion concentration in the root solution may therefore impose a competition between minerals, and a scarcity or an excess of minerals can have a substantial effect on plant development (White, 2012).

Similar to results for the vegetative stage (Shiponi and Bernstein, 2021), N and $\mathrm{K}$ concentrations in the leaves, stem, and roots did not show a consistent trend in response to $\mathrm{P}$ nutrition between varieties (Figures 5, 6), demonstrating a genetic variability in mineral acquisition, translocation, and accumulation (Clárk, 1983). Some variations in the effect of $\mathrm{P}$ on mineral concentrations in the plant organs between the reproductive and the vegetative stages, such as for $\mathrm{N}$ and $\mathrm{P}$ in leaves (Shiponi and Bernstein, 2021), demonstrate also a developmental stage dependency.

An increase in $\mathrm{Mg}$ concentration in leaves up to $30 \mathrm{mg}$ $\mathrm{L}^{-1} \mathrm{P}$ supply was observed at both stages of development for both genotypes. In Shiponi and Bernstein (2021), we proposed acidification of the rhizosphere as a mechanism to induce $\mathrm{Ca}$ and $\mathrm{Mg}$ deficiency under P restriction. In support of this notion, leachate $\mathrm{pH}$, in the current study for plants grown under $\mathrm{P}$ deficiency $\left(5 \mathrm{mg} \mathrm{L}^{-1}\right)$, was lower $(\mathrm{pH} 4.5)$ than for plants grown under adequate $\mathrm{P}$ nutrition ( $\mathrm{pH}$ 5.8) (Supplementary Figure 3).

Bioaccumulation of heavy metals in food crops and medicinal plants is a matter of concern worldwide due to their toxic effects on human health (Chizzola et al., 2003). Zn, Mn, Fe, Cu, Mo, and $\mathrm{Ni}$ are essential heavy metals that can be absorbed by plants via root uptake and accumulate to high concentrations (Ashfaque et al., 2016; Goyal et al., 2020). Variability in the extent of uptake and accumulation of heavy metal nutrients in plants is well documented between and within species, and C. sativa (hemp) was recognized as a hyper accumulator for heavy metals and is therefore considered a good candidate for soil phytoremediation (Citterio et al., 2003; Sarma et al., 2020). Hence, to maintain a safe product, data on the bioaccumulation potential of microelements in medical cannabis plant organs is required.

A decline in Mn concentration in the stem with $\mathrm{P}$ addition, and a maximum curve in leaves' Mn (Figures 5F, 6F) were obtain also at the vegetative stage (Shiponi and Bernstein, 2021). Manganese is easily translocated from root to shoot with the transpiration stream in the xylem sap and but it moves poorly in the phloem (Loneragan, 1988; Duèiæ and Polle, 2005). Therefore, remobilization is limited, and $\mathrm{Mn}$ accumulates to higher concentrations in mature leaves than in young leaves. The retention of $\mathrm{Mn}$ in the root under low $\mathrm{P}$ supply in medicinal cannabis may reflect the lower transpiration rate in the 5 and $15 \mathrm{mg} \mathrm{L}^{-1} \mathrm{P}$ treatments. When Mn levels are adequate, high concentrations of $\mathrm{Mn}$ can be stored in the roots and the stem and translocate to the shoot when Mn deficiency conditions develop (Clarkson, 1988; Loneragan, 1988). Generally, Mn accumulates in the root under sufficient Mn level (Loneragan, 1988), although a higher shoot/root ratio of Mn concentration is also common (Xue et al., 2004; Farzadfar et al., 2017). Baker (1981) discussed two strategies of plant response to tolerate metal toxicity: accumulators and excluders. Accumulators usually transport the metals to the aerial parts, while the excluders' response involves maintaining a low concentration in the shoot. Polechońska et al. (2013) found that the bioaccumulator plant, Polygonum aviculare, accumulates essential micronutrients ( $\mathrm{Zn}$, $\mathrm{Mn}$, and $\mathrm{Cu}$ ) in the aerial parts, unlike unessential elements that are accumulated in the root $(\mathrm{Cd}, \mathrm{Ni}$, and $\mathrm{Pb})$. Xue et al. (2004) documented that in the hyperaccumulator plant Phytolacca acinosa, $87-95 \%$ of the $\mathrm{Mn}$ was translocated to the shoot. In medicinal cannabis, we found that at the vegetative-stage Mn was retained in the root, whereas at the reproductive stage the highest concentrations in the shoot were found under adequate $\mathrm{P}$ nutrition. Cannabis is known as a good bioaccumulator; thus, accumulation in the shoot is not surprising. The plant strategy can be transformed from excluder to accumulator during the plant life cycle (Baker, 1981), and it may be the reason for the differences between $\mathrm{Mn}$ accumulation in the plant organs at different development stages.

We identified a decrease in $\mathrm{Zn}$ concentrations in the root with the increase in $\mathrm{P}$ concentration in both the vegetative and the reproductive phase for both cultivars, and the $\mathrm{P} \times \mathrm{Zn}$ interaction was discussed in detail in Shiponi and Bernstein (2021). Inflorescence $\mathrm{Zn}$ concentration was $\sim 40 \%$ higher in DQ compared with RM, demonstrating a genetic variability. Genetic variability was reported before to affect heavy metal accumulation in plants (Baker and Brooks, 1989; Malik et al., 2010), and in cannabis, it can be explored for reduction of heavy metal accumulation in the pharmaceutical product.

The safety of medicinal cannabis consumption and the safe limit of heavy metal concentration in the product are not yet well researched and are topics of interest in light of the growing global demand. Thus, there is an increasing necessity for the 
regulation and restriction of heavy metal concentrations in medicinal cannabis (Gauvin et al., 2018; Nie et al., 2019). Further research on the effect of the plant genotype and environmental factors in relation to heavy metal acquisition is necessary.

\section{Cannabinoids}

Cannabis is one of the oldest plant sources for medicine. It is known for centuries for its medicinal potential and has been used traditionally for thousands of years for the treatment of a wide array of ailments (Gonçalves et al., 2019). Recent changes in regulations have allowed proliferation of medical studies, and significant progress has been made toward the understanding of the potential of the plant-produced cannabinoids, and their interactions with other biologically active secondary metabolites in the plant, for modern medicine (Citti et al., 2018). Filling the medical knowledge gap, as well as knowledge concerning the influence of agro-technologies on the concentrations and ratios between the pharmacological compounds, is of high priority for optimizing the medicinal value of the product.

The production of secondary metabolites is known to be affected by environmental factors (Verpoorte et al., 2002; Ramakrishna and Ravishankar, 2011; Gorelick and Bernstein, 2014). Among other secondary metabolites, cannabis plants produce cannabinoids that are biosynthesized and stored in trichomes located mainly on the plant inflorescence. Cannabis plants differ in their cannabinoid contents due to genetic and environmental factors (Chandra et al., 2017; Danziger and Bernstein, 2021a). Abiotic stressors were found to induce changes in the cannabinoid profile in the cannabis plant (Flores-Sanches and Verpoorte, 2008; Backer et al., 2019; Caplan et al., 2019; Jalali et al., 2019; Gülck and Møller, 2020; Yep et al., 2020; Saloner and Bernstein, 2021), and in the current study, P nutrition was found to elicit changes in cannabinoid concentrations in the two genotypes tested. We found a reduction in concentrations of most tested cannabinoids with an increase in P application (Figure 9), which negatively correlated with yield production (Figure 11). Although the concentrations of many cannabinoids (especially THCA and CBDA) reduced, the amount of cannabinoids produced per plant increased with $\mathrm{P}$, suggesting that the optimal $\mathrm{P}$ application is $30 \mathrm{mg} \mathrm{L}^{-1}$ in DQ and $30-90 \mathrm{mg} \mathrm{L}^{-1}$ in RM (Figure 10).

Previous studies on $\mathrm{P}$ effect on secondary metabolites and essential oil production found a variety of responses to increased $\mathrm{P}$ application. $\mathrm{P}$ increased essential oil production in Cymbopogon nardus (Ranaweera and Thilakaratne, 1992; Ranaweera et al., 1992), Olearia phlogopappa (Dragar and Menary, 1995), cannabis (Coffman and Gentner, 1977), dragonhead (Said-Al Ahl and Abdou, 2009), and basil (Ichimura et al., 1995). Essential oil content was not affected by $\mathrm{P}$ in sage (Rioba et al., 2015) and basil (Ichimura et al., 1995) and by a moderate P application in cannabis (Bernstein et al., 2019b) and was reduced in Olearia phlogopappa (Dragar and Menary, 1995). An increase in THCA and CBDA concentrations as a response to $\mathrm{P}$ deficiency are unlikely to be a direct effect of $\mathrm{P}$ on the biochemical pathways due to the crucial role of $\mathrm{P}$ in cannabinoid biosynthesis (Fellermeier et al., 2001; Flores-Sanches and Verpoorte, 2008; Sarma et al., 2020). The negative correlation between THCA and CBDA, and inflorescence yield production (Figure 11) indicates that a dilution effect may be a possible mechanism for the reduction in their concentration.

When Pearson correlation coefficient was performed on THCA, CBDA, and total $\mathrm{P}$ in the plant, the correlation was weaker compared to yield production $\left(R^{2}=\mathrm{RM}: 0.59,0.37\right.$ and DQ: $0.32,0.31$ for THCA and CBDA, respectively). The lower correlation with $\mathrm{P}$ compared with inflorescence yield suggests that the influence on the cannabinoid concentrations is probably due to yield increase and not a direct effect of $\mathrm{P}$. Caplan et al. (2017) found, that in cannabis, NPK application reduced THCA, THC, and CBGA concentration and increased yield. Corresponding to our results, a negative correlation between THCA and inflorescence yield was found, and the total cannabinoids per plant increased with NPK. In our study, both genotypes analyzed responded similarly to the $\mathrm{P}$ treatments, and only minor changes were observed, this is despite the very different chemovars (a high THC vs. a CBD/THC balanced profile). Unlike DQ that did not show a response to $\mathrm{P}$ addition above $30 \mathrm{mg} \mathrm{L}^{-1}$ in total cannabinoid production, $\mathrm{RM}$ responded with a slight increase that might indicate a potential for yield increase with $\mathrm{P}$ addition for certain genotypes, which should be tested further. The reduction in THCA concentration in response to $\mathrm{P}$ addition was slightly higher for $\mathrm{RM}$ compared with DQ; THCVA was reduced with $\mathrm{P}$ in $\mathrm{RM}$ and was only slightly affected in DQ.

These results demonstrate that the effect of $\mathrm{P}$ nutrition on the cannabinoid profile may be genotype specific, and genetic differences should be explored for the optimization of the secondary metabolite profile by P-nutrition technologies. More research is needed on medicinal effects of cannabinoids and their interactions, in order to direct growing techniques for production of medical product with a desirable cannabinoid profile.

\section{In Summary}

Phosphorus nutrition considerably affects morpho-physiology of medicinal cannabis and its chemical profile. No signs of $\mathrm{P}$ toxicity were found under the concentration range tested; however, at the two lowest $\mathrm{P}$ supply rates (5 and $15 \mathrm{mg} \mathrm{L}^{-1} \mathrm{P}$ ), $\mathrm{P}$ deficiency reduced plant growth and physiological function, induced leaf chlorosis, but increased root/shoot ratio and PUE. Moreover, $80 \%$ yield efficiency was achieved under $30 \mathrm{mg} \mathrm{L}^{-1}$ $\mathrm{P}$ supply in both genotypes but was higher for DQ. Although both genotypes responded similarly to the $\mathrm{P}$ application dosages, DQ's yield production was not affected by $\mathrm{P}$ addition above $30 \mathrm{mg} \mathrm{L}^{-1}$, unlike $\mathrm{RM}$ that responded with a small increase to $\mathrm{P}$ addition up to $90 \mathrm{mg} \mathrm{L}^{-1} \mathrm{P}$. Thereby, DQ demonstrated best performance under lower $\mathrm{P}$ application compared with RM that slightly increased in yield under high $\mathrm{P}$ supply. Taken together, our results demonstrate that the optimal $\mathrm{P}$ nutrition needs to be adjusted to the target product. The lowest recommended $\mathrm{P}$ supply for optimal yield quantity is $30 \mathrm{mg} \mathrm{L}^{-1} \mathrm{P}$; under higher concentrations up to $90 \mathrm{mg} \mathrm{L}^{-1} \mathrm{P}$, yield quantity remains optimal; and $\mathrm{P}$ deficiency stress $\left(5-15 \mathrm{mg} \mathrm{L}^{-1} \mathrm{P}\right)$ can be used to stimulate higher concentrations of the major cannabinoids. More research needs to be conducted on specific genotypic responses to $\mathrm{P}$ addition above the optimal dosage. 


\section{DATA AVAILABILITY STATEMENT}

The original contributions presented in the study are included in the article/Supplementary Material, further inquiries can be directed to the corresponding author/s.

\section{AUTHOR CONTRIBUTIONS}

NB planned the experiments. SS carried out the experiments. NB and SS wrote the manuscript. Both authors contributed to the article and approved the submitted version.

\section{FUNDING}

This study was funded by the Chief Scientist Fund of the Ministry of Agriculture in Israel, grant no. 20-03-0018.

\section{REFERENCES}

Aerts, R. (1996). Nutrient resorption from senescing leaves of perennials: are there general patterns? J. Ecol. 84, 597-608. doi: 10.2307/2261481

Allaway, W. G., and Mansfield, T. A. (1967). Stomatal responses to changes in carbon dioxide concentration in leaves treated with 3-(4-chlorophenyl)-1, 1-dimethylurea. New Phytol. 66, 57-63. doi: 10.1111/j.1469-8137.1967.tb05 986.x

Ashfaque, F., Inam, A., Sahay, S., and Iqbal, S. (2016). Influence of heavy metal toxicity on plant growth, metabolism and its alleviation by phytoremediation-a promising technology. J. Agric. Ecol. Res. Int. 6, 1-19. doi: 10.9734/JAERI/2016/ 23543

Backer, R., Schwinghamer, T., Rosenbaum, P., McCarty, V., Eichhorn Bilodeau, S., Lyu, D., et al. (2019). Closing the yield gap for cannabis: a meta-analysis of factors determining cannabis yield. Front. Plant Sci. 10:495. doi: 10.3389/fpls. 2019.00495

Baker, A. J. M. (1981). Accumulators and excluders-strategies in the response of plants to heavy metals. J. Plant Nutr. 3, 643-654. doi: 10.1080/ 01904168109362867

Baker, A. J. M., and Brooks, R. R. (1989). Terrestrial higher plants which hyperaccumulate metallic elements. a review of their distribution, ecology and phytochemistry. Biorecovery 1, 81-126.

Balemi, T., and Schenk, M. K. (2009a). Genotypic difference of potato in carbon budgeting as a mechanism of phosphorus utilization efficiency. Plant Soil 322, 91-99. doi: 10.1007/s11104-009-9897-0

Balemi, T., and Schenk, M. K. (2009b). Genotypic variation of potato for phosphorus efficiency and quantification of phosphorus uptake with respect to root characteristics. J. Plant Nutr. Soil Sci. 172, 669-677. doi: 10.1002/jpln. 200800246

Batten, G. D. (1992). A review of phosphorus efficiency in wheat. Plant Soil 146, 163-168. doi: 10.1007/BF00012009

Berman, P., Futoran, K., Lewitus, G. M., Mukha, D., Benami, M., Shlomi, T., et al. (2018). A new ESI-LC/MS approach for comprehensive metabolic profiling of phytocannabinoids in Cannabis. Sci. Rep. 8:14280. doi: 10.1038/s41598-01832651-4

Bernstein, N., Gorelick, J., and Koch, S. (2019a). Interplay between chemistry and morphology in medical cannabis (Cannabis sativa L .). Ind. Crop. Prod. 129, 185-194. doi: 10.1016/j.indcrop.2018.11.039

Bernstein, N., Gorelick, J., Zerahia, R., and Koch, S. (2019b). Impact of N, P, K, and humic acid supplementation on the chemical profile of medical Cannabis (Cannabis sativa L). Front. Plant Sci. 10:736. doi: 10.3389/fpls.2019.00736

Bieleski, R. L. (1973). Phosphate pools, phosphate transport, and phosphate availability. Annu. Rev. Plant Physiol. 24, 225-252. doi: 10.1146/annurev.pp. 24.060173.001301

\section{ACKNOWLEDGMENTS}

We thank Dr. Mollie Sacks for advice concerning the design of the fertigation solutions, Yael Sade for guidance concerning cannabinoid analysis, Shiran Cohen for assistance with $\mathrm{N}$ and P analysis, and Dalit Morad, Guy Cohen, Geki Shoef, Ayana Neta, Eliav Shtul-Trauring, Avia Saloner, and Nadav Danziger for technical assistance. We also thank Gerry Kolin, Teva Adir, Ltd., a certified commercial growing company for the supply of the plant material for the study.

\section{SUPPLEMENTARY MATERIAL}

The Supplementary Material for this article can be found online at: https://www.frontiersin.org/articles/10.3389/fpls.2021. 657323/full\#supplementary-material

Bonini, S. A., Premoli, M., Tambaro, S., Kumar, A., Maccarinelli, G., Memo, M., et al. (2018). Cannabis sativa: a comprehensive ethnopharmacological review of a medicinal plant with a long history. J. Ethnopharmacol. 227, 300-315. doi: 10.1016/j.jep.2018.09.004

Brooks, A. (1986). Effects of phosphorus nutrition on ribulose-1, 5-bisphosphate carboxylase activation, photosynthetic quantum yield and amounts of some Calvin-cycle metabolites in spinach leaves. Funct. Plant Biol. 13, 221-237. doi: 10.1071/PP9860221

Brooks, A. (1988). Effects of phosphorus nutrition on the response of photosynthesis to $\mathrm{CO} 2$ and $\mathrm{O} 2$, activation of ribulose bisphosphate carboxylase and amounts of ribulose bisphosphate and 3-phosphoglycerate in spinach leaves. Photosynth. Res. 15, 133-141. doi: 10.1007/BF00035257

Caplan, D., Dixon, M., and Zheng, Y. (2017). Optimal rate of organic fertilizer during the flowering stage for cannabis grown in two coir-based substrates. HortScience 52, 1796-1803. doi: 10.21273/HORTSCI12401-17

Caplan, D., Dixon, M., and Zheng, Y. (2019). Increasing inflorescence dry weight and cannabinoid content in medical cannabis using controlled drought stress. HortScience 54, 964-969. doi: 10.21273/HORTSCI13510-18

Chandra, S., Lata, H., Khan, I. A., and ElSohly, M. A. (2017). Cannabis sativa L.-Botany and Biotechnology. Berlin: Springer. doi: 10.1007/978-3-319-54564-6

Chizzola, R., Michitsch, H., and Franz, C. (2003). Monitoring of metallic micronutrients and heavy metals in herbs, spices and medicinal plants from Austria. Eur. Food Res. Technol. 216, 407-411. doi: 10.1007/s00217-0030675-6

Citterio, S., Santagostino, A., Fumagalli, P., Prato, N., Ranalli, P., and Sgorbati, S. (2003). Heavy metal tolerance and accumulation of $\mathrm{Cd}, \mathrm{Cr}$ and $\mathrm{Ni}$ by Cannabis sativa L. Plant Soil 256, 243-252. doi: 10.1023/A:1026113905129

Citti, C., Braghiroli, D., Vandelli, M. A., and Cannazza, G. (2018). Pharmaceutical and biomedical analysis of cannabinoids: a critical review. J. Pharm. Biomed. Anal. 147, 565-579. doi: 10.1016/j.jpba.2017.06.003

Clárk, R. B. (1983). Plant genotype differences in the uptake, translocation, accumulation, and use of mineral elements required for plant growth. Genet. Aspects Plant Nutr. 72, 49-70. doi: 10.1007/978-94-009-6836-3_5

Clarke, R. C., and Merlin, M. D. (2016). Cannabis domestication, breeding history, present-day genetic diversity, and future prospects. Crit. Rev. Plant Sci. 35, 293-327. doi: 10.1080/07352689.2016.1267498

Clarkson, D. T. (1988). The uptake and translocation of manganese by plant roots. Manganese Soils Plants 33, 101-111. doi: 10.1007/978-94-009-2817-6_8

Clarkson, D. T., and Hanson, J. B. (1980). The mineral nutrition of higher plants. Annu. Rev. Plant Physiol. 31, 239-298. doi: 10.1146/annurev.pp.31.060180. 001323

Coffman, C. B., and Gentner, W. A. (1977). Responses of greenhouse-grown Cannabis sativa L. to nitrogen, phosphorus, and potassium 1. Agron. J. 69, 832-836. doi: 10.2134/agronj1977.00021962006900050026x 
Danziger, N., and Bernstein, N. (2021a). Light matters: effect of light spectra on cannabinoid profile and plant development of medicinal cannabis (Cannabis sativa L.). Indust. Crop Prod. 194:113351. doi: 10.1016/j.indcrop.2021.113351

Danziger, N., and Bernstein, N. (2021b). Plant architecture manipulation increases cannabinoid standardization in 'drug-type' medical cannabis. Indust. Crop Prod. 167:113528. doi: 10.1016/j.indcrop.2021.113528

Decorte, T., and Potter, G. (2015). The globalisation of cannabis cultivation: a growing challenge. Int. J. Drug Policy 26, 221-225. doi: 10.1016/j.drugpo.2014. 12.011

Demain, A. L., and Fang, A. (2000). "The natural functions of secondary metabolites," in History of Modern Biotechnology I, ed. A. Fiechter (Berlin: Springer). doi: 10.1007/3-540-44964-7_1

Dong, B., Ryan, P. R., Rengel, Z., and Delhaize, E. (1999). Phosphate uptake in Arabidopsis thaliana: dependence of uptake on the expression of transporter genes and internal phosphate concentrations. Plant Cell Environ. 22, 14551461. doi: $10.1046 / j .1365-3040.1999 .00500 . x$

Dragar, V. A., and Menary, R. C. (1995). Mineral nutrition of olearia phlogopappa: effect on growth, essential oil yield, and composition. Commun. Soil Sci. Plant Anal. 26, 1299-1313. doi: 10.1080/00103629509369372

Duèiæ, T., and Polle, A. (2005). Transport and detoxification of manganese and copper in plants. Braz. J. Plant Physiol. 17, 103-112. doi: 10.1590/S167704202005000100009

Engels, C., Kirkby, E., and White, P. (2012). "Mineral nutrition, yield and source sink relationships," in Marschner"s Mineral Nutrition of Higher Plants, ed. P. Marschner (London: Academic Press), 85-134. doi: 10.1016/B978-0-12384905-2.00005-4

Farzadfar, S., Zarinkamar, F., and Hojati, M. (2017). Magnesium and manganese affect photosynthesis, essential oil composition and phenolic compounds of Tanacetum parthenium. Plant Physiol. Biochem. 112, 207-217. doi: 10.1016/j. plaphy.2017.01.002

Fellermeier, M., Eisenreich, W., Bacher, A., and Zenk, M. H. (2001). Biosynthesis of cannabinoids: incorporation experiments with 13C-labeled glucoses. Eur. J. Biochem. 268, 1596-1604. doi: 10.1046/j.1432-1327.2001.02030.x

Flores-Sanches, J., and Verpoorte, R. (2008). Secondary metabolism in cannabis. Phytochem. Rev. 7, 615-639. doi: 10.1007/s11101-008-9094-4

Föhse, D., Claassen, N., and Jungk, A. (1988). Phosphorus efficiency of plants. Plant Soil 110, 101-109. doi: 10.1007/BF02143545

Fredeen, A. L., Raab, T. K., Rao, I. M., and Terry, N. (1990). Effects of phosphorus nutrition on photosynthesis in Glycine max (L.) Merr. Planta 181, 399-405. doi: 10.1007/BF00195894

Frydenvang, J., van Maarschalkerweerd, M., Carstensen, A., Mundus, S., Schmidt, S. B., Pedas, P. R., et al. (2015). Sensitive detection of phosphorus deficiency in plants using chlorophyll a fluorescence. Plant Physiol. 169, 353-361. doi: 10.1104/pp.15.00823

Gauvin, D. V., Zimmermann, Z. J., Yoder, J., and Tapp, R. (2018). Marijuana toxicity: heavy metal exposure through state-sponsored access to "la Fee Verte". Pharm. Regul. Aff. Open Access 7, 1-10. doi: 10.4172/2167-7689.1000202

George, E., Horst, W. J., and Neumann, E. (2012). "Adaptation of plants to adverse chemical soil conditions," in Marschner"s Mineral Nutrition of Higher Plants, ed. P. Marschner (Cambridge: Academic Press). doi: 10.1016/B978-0-12-3849052.00017-0

Gonçalves, J., Rosado, T., Soares, S., Simão, A., Caramelo, D., Luís, Â, et al. (2019). Cannabis and its secondary metabolites: their use as therapeutic drugs, toxicological aspects, and analytical determination. Medicines 6:31. doi: 10. 3390/medicines6010031

Gorelick, J., and Bernstein, N. (2014). Elicitation: an underutilized tool in the development of medicinal plants as a source of therapeutic secondary metabolites. Adv. Agronomy 124, 201-230. doi: 10.1016/B978-0-12-8001387.00005-X

Gorelick, J., and Bernstein, N. (2017). "Chemical and physical elicitation for enhanced cannabinoid production in cannabis," in Cannabis sativa L. - Botany and Biotechnology, eds S. Chandra, H. Lata, and M. ElSohly (Cham: Springer). doi: 10.1007/978-3-319-54564-6_21

Gourley, C. J. P., Allan, D. L., and Russelle, M. P. (1993). Defining phosphorus efficiency in plants. Plant Soil 155, 289-292. doi: 10.1007/BF0002 5039
Goyal, D., Yadav, A., Prasad, M., Singh, T. B., Shrivastav, P., Ali, A., et al. (2020). "Effect of heavy metals on plant growth: an overview," in Contaminants in Agriculture, eds G. S. Naeem and A. Ansari (Cham: Springer). doi: 10.1007/9783-030-41552-5_4

Grabau, L. J., Blevins, D. G., and Minor, H. C. (1986). P nutrition during seed development: leaf senescence, pod retention, and seed weight of soybean. Plant Physiol. 82, 1008-1012. doi: 10.1104/pp.82.4.1008

Gülck, T., and Møller, B. L. (2020). Phytocannabinoids: origins and biosynthesis. Trends Plant Sci. 25, 985-1004. doi: 10.1016/j.tplants.2020.05.005

Hawkesford, M., Horst, W., Kichey, T., Lambers, H., Schjoerring, J., Skrumsager, I., et al. (2012). "Functions of macronutrients," in Marschner"s Mineral Nutrition of Higher Plants, ed. P. Marschner (London: Academic Press). doi: 10.1016/B9780-12-384905-2.00006-6

Hocking, P. J., and Pate, J. S. (1978). Accumulation and distribution of mineral elements in the annual lupins Lupinus albus L. and Lupinus angustifolius L. Aust. J. Agric. Res. 29, 267-280. doi: 10.1071/AR9780267

Ichimura, M., Ikushima, M., Miyazaki, T., and Kiruma, M. (1995). Effect of phosphorus on growth and concentration of mineral elements ans essensial oils of sweet basil leaves. Hydroponics Transpl. Prod. 396, 195-202. doi: 10.17660/ ActaHortic.1995.396.23

Iványi, I., and Izsáki, Z. (2009). Effect of nitrogen, phosphorus, and potassium fertilization on nutrional status of fiber hemp. Commun. Soil Sci. Plant Anal. 40, 974-986. doi: 10.1080/00103620802693466

Jalali, S., Salami, A. S., Sharifi, M., and Sohrabi, S. (2019). Signaling compounds elicit expression of key genes in cannabinoid pathway and related metabolites in cannabis. Ind. Crops Prod. 133, 105-110. doi: 10.1016/j.indcrop.2019.03.004

Kirkby, E. (2012). "Introduction,definition and classification of nutrients," in Marschner"s Mineral Nutrition of Higher Plants, ed. P. Marschner (London: Academic Press). doi: 10.1016/B978-0-12-384905-2.00001-7

Lichtenthaler, K., and Welburn, A. R. (1983). Determination of total carotenoids and chlorophylls A and B of leaf extracts in different solvents. Biochem. Soc. Trans. 11, 591-592. doi: 10.1042/bst0110591

Liu, T. Y., Huang, T. K., Yang, S. Y., Hong, Y. T., Huang, S. M., Wang, F. N., et al. (2016). Identification of plant vacuolar transporters mediating phosphate storage. Nat. Commun. 7:11095. doi: 10.1038/ncomms11095

Loneragan, J. F. (1988). "Distribution and movement of manganese in plants," in Manganese in Soils and Plants. Developments in Plant and Soil Sciences, eds R. D. Graham, R. D. Hannam, and N. C. Uren (Dordrecht: Springer).

Magagnini, G., Grassi, G., and Kotiranta, S. (2018). The effect of light spectrum on the morphology and cannabinoid content of Cannabis sativa L. Med. Cannabis Cannabinoids 1, 19-27. doi: 10.1159/000489030

Malfait, A. M., Gallily, R., Sumariwalla, P. F., Malik, A. S., Andreakos, E., Mechoulam, R., et al. (2000). The nonpsychoactive cannabis constituent cannabidiol is an oral anti-arthritic therapeutic in murine collagen-induced arthritis. Proc. Natl. Acad. Sci. 97, 9561-9566. doi: 10.1073/pnas.16010 5897

Malik, R. N., Husain, S. Z., and Nazir, I. (2010). Heavy metal contamination and accumulation in soil and wild plant species from industrial area of Islamabad. Pakistan. Pakistan J. Bot. 42, 291-301.

Milay, L., Berman, P., Shapira, A., Guberman, O., and Meiri, D. (2020). Metabolic profiling of Cannabis secondary metabolites for evaluation of optimal postharvest storage conditions. Front. Plant Sci. 11:583605. doi: 10. 3389/fpls.2020.583605

Mimura, T. (1999). "Regulation of phosphate transport and homeostasis in plant cells," in International Review of Cytology, ed. K. W. Jeon (Cambridge: Academic Press). doi: 10.1016/S0074-7696(08)60159-X

Neocleous, D., and Savvas, D. (2019). The effects of phosphorus supply limitation on photosynthesis, biomass production, nutritional quality, and mineral nutrition in lettuce grown in a recirculating nutrient solution. Sci. Hortic. 252, 379-387. doi: 10.1016/j.scienta.2019.04.007

Nie, B., Henion, J., and Ryona, I. (2019). The role of mass spectrometry in the cannabis industry. J. Am. Soc. Mass Spectrom. 30, 719-730. doi: 10.1007/ s13361-019-02164-z

Nussaume, L., Kanno, S., Javot, H., Marin, E., Pochon, N., Ayadi, A., et al. (2011). Phosphate import in plants: focus on the PHT1 transporters. Front. Plant Sci. 2:83. doi: $10.3389 /$ fpls.2011.00083 
Ozturk, L., Eker, S., Torun, B., and Cakmak, I. (2005). Variation in phosphorus efficiency among 73 bread and durum wheat genotypes grown in a phosphorusdeficient calcareous soil. Plant Soil 269, 69-80. doi: 10.1007/s11104-0040469-z

Pant, B. D., Pant, P., Erban, A., Huhman, D., Kopka, J., and Scheible, W. R. (2015). Identification of primary and secondary metabolites with phosphorus statusdependent abundance in Arabidopsis, and of the transcription factor PHR1 as a major regulator of metabolic changes during phosphorus limitation. Plant Cell Environ. 38, 172-187. doi: 10.1111/pce.12378

Polechońska, M., Zawadzki, K., Samecka-Cymerman, A., Kolon, K., Klink, A., Krawczyk, J., et al. (2013). Evaluation of the bioindicator suitability of polygonum aviculare in urban areas. Ecol. Indic. 24, 552-556. doi: 10.1016/j. ecolind.2012.08.012

Ramakrishna, A., and Ravishankar, G. A. (2011). Influence of abiotic stress signals on secondary metabolites in plants. Plant Signal. Behav. 6, 1720-1731. doi: 10.4161/psb.6.11.17613

Ranaweera, S. S., and Thilakaratne, W. P. (1992). Mineral nutrition of Cymbopogon nardus (L) rendle: part II. effects of magnesium and phosphorus nutrition on the fractional composition of essential oil. Vidyodaya J. Sci. 4, 209-219. doi: 10.4038/vjs.v4i1.6081

Ranaweera, S. S., Thilakaratne, W. P., and Thilakaratne, W. P. (1992). Mineral nutrition of Cymbopogon nardus (L) rendle: part I. effects of magnesium and phosphorus nutrition on growth and the yield of essential oil. Vidyodaya J. Sci. 4, 201-208. doi: 10.4038/vjs.v4i1.6080

Rioba, N. B., Itulya, F. M., Saidi, M., Dudai, N., and Bernstein, N. (2015). Effects of nitrogen, phosphorus and irrigation frequency on essential oil content and composition of sage (Salvia officinalis L.). J. Appl. Res. Med. Aromat. Plants 2, 21-29. doi: 10.1016/j.jarmap.2015.01.003

Rose, T. J., Pariasca-Tanaka, J., Rose, M. T., Fukuta, Y., and Wissuwa, M. (2010). Genotypic variation in grain phosphorus concentration, and opportunities to improve P-use efficiency in rice. Field Crops Res. 119, 154-160. doi: 10.1016/j. fcr.2010.07.004

Rose, T. J., Rengel, Z., Ma, Q., and Bowden, J. W. (2007). Differential accumulation patterns of phosphorus and potassium by canola cultivars compared to wheat. J. Plant Nutr. Soil Sci. 170, 404-411. doi: 10.1002/jpln.20062 5163

Rose, T. J., Rengel, Z., Ma, Q., and Bowden, J. W. (2008). Post-flowering supply of P, but not K, is required for maximum canola seed yields. Eur. J. Agron. 28, 371-379. doi: 10.1016/j.eja.2007.11.003

Russo, E. B. (2011). Taming THC: potential cannabis synergy and phytocannabinoid-terpenoid entourage effects. Br. J. Pharmacol. 163, 1344-1364. doi: 10.1111/j.1476-5381.2011.01238.x

Said-Al Ahl, H. A. H., and Abdou, M. A. A. (2009). Impact of water stress and phosphorus fertilizer on fresh herb and essential oil content of dragonhead. Int. Agrophys. 23, 403-407.

Saloner, A., and Bernstein, N. (2020). Response of medical cannabis (Cannabis sativa L.) to nitrogen supply under long photoperiod. Front. Plant Sci. 11:572293. doi: $10.3389 /$ fpls.2020.572293

Saloner, A., and Bernstein, N. (2021). Nitrogen supply affects cannabinoid and terpenoid profile in medical cannabis (Cannabis sativa L.). Ind. Crop. Prod. 167:113516. doi: 10.1016/j.indcrop.2021.113516

Saloner, A., Sacks, M. M., and Bernstein, N. (2019). Response of medical cannabis (Cannabis sativa L .) genotypes to $\mathrm{K}$ supply under long photoperiod. Front. Plant Sci. 10:1369. doi: 10.3389/fpls.2019.01369

Sarma, N. D., Waye, A., Elsohly, M. A., Brown, P. N., Elzinga, S., Johnson, H. E., et al. (2020). Cannabis inflorescence for medical purposes: USP considerations for quality attributes. J. Nat. Prod. 83, 1334-1351. doi: 10.1021/acs.jnatprod. $9 \mathrm{~b} 01200$

Shane, M. W., McCully, M. E., and Lambers, H. (2004). Tissue and cellular phosphorus storage during development of phosphorus toxicity in Hakea prostrata (Proteaceae). J. Exp. Bot. 55, 1033-1044. doi: 10.1093/jxb/erh111

Shen, J., Yuan, L., Zhang, J., Li, H., Bai, Z., Chen, X., et al. (2011). Phosphorus dynamics: from soil to plant. Plant Physiol. 156, 997-1005. doi: 10.1104/pp. 111.175232

Shiponi, S., and Bernstein, N. (2021). Response of medical cannabis (Cannabis sativa L.) genotypes to $\mathrm{P}$ supply under long photoperiod: functional phenotyping and the ionome. Ind. Crops Prod. 161:113154. doi: 10.1016/j. indcrop.2020.113154

Small, E. (2018). Dwarf germplasm: the key to giant Cannabis hempseed and cannabinoid crops. Genet. Resour. Crop Evol. 65, 1071-1107. doi: 10.1007/ s10722-017-0597-y

Snapp, S. S., and Lynch, J. P. (1996). Phosphorus distribution and remobilization in bean plants as influenced by phosphorus nutrition. Crop Sci. 36, 929-935. doi: 10.2135/cropsci1996.0011183X003600040019x

Soltangheisi, A., Fauziah Ishak, C., Mohamed Musa, H., Zakikhani, H., and Abdul Rahman, Z. (2013). Phosphorus and zinc uptake and their interaction effect on dry matter and chlorophyll content of sweet com (Zea mays var. saccharata). J. Agron. 12, 187-192. doi: 10.3923/ja.2013.187.192

Taliman, N. A., Dong, Q., Echigo, K., Raboy, V., and Seneoka, H. (2019). Effect of phosphorus fertilization on the growth, photosynthesis, nitrogen fixation, mineral accumulation, seed yield, and seed quality of a soybean low-phytate line. Plants 8:119. doi: 10.3390/plants8050119

Tang, Y., Wen, X., and Lu, C. (2005). Differential changes in degradation of chlorophyll-protein complexes of photosystem I and photosystem II during flag leaf senescence of rice. Plant Physiol. Biochem. 43, 193-201. doi: 10.1016/j. plaphy.2004.12.009

Turner, J. C., Hemphill, J. K., and Mahlberg, P. G. (1978). Quantitative determination of cannabinoids in individual glandular trichomes of Cannabis Sativa L. (Cannabaceae). Am. J. Bot. 65, 1103-1106. doi: 10.1002/j.1537-2197. 1978.tb06177.x

Veneklaas, E. J., Lambers, H., Bragg, J., Finnegan, P. M., Lovelock, C. E., Plaxton, W. C., et al. (2012). Opportunities for improving phosphorus-use efficiency in crop plants. New Phytol. 195, 306-320. doi: 10.1111/j.1469-8137.2012. 04190.x

Vera, C. L., Malhi, S. S., Phelps, S. M., May, W. E., and Johnson, E. N. (2010). N, P, and $S$ fertilization effects on industrial hemp in Saskatchewan. Can. J. Plant Sci. 90, 179-184. doi: 10.4141/CJPS09101

Vera, C. L., Malhi, S. S., Raney, J. P., and Wang, Z. H. (2004). The effect of N and P fertilization on growth, seed yield and quality of industrial hemp in the Parkland region of Saskatchewan. Can. J. Plant Sci. 84, 939-947. doi: 10.4141/P04-022

Verpoorte, R., Contin, A., and Memelink, J. (2002). Biotechnology for the production of plant secondary metabolites. Phytochem. Rev. 1, 13-25. doi: 10.1023/A:1015871916833

Wang, J., Chen, Y., Wang, P., Li, Y. S., Wang, G., Liu, P., et al. (2018). Leaf gas exchange, phosphorus uptake, growth and yield responses of cotton cultivars to different phosphorus rates. Photosynthetica 56, 1414-1421. doi: 10.1007/ s11099-018-0845-1

Wang, X., Shen, J., and Liao, H. (2010a). Acquisition or utilization, which is more critical for enhancing phosphorus efficiency in modern crops? Plant Sci. 179, 302-306. doi: 10.1016/j.plantsci.2010.06.007

Wang, X., Yan, X., and Liao, H. (2010b). Genetic improvement for phosphorus efficiency in soybean: a radical approach. Ann. Bot. 106, 215-222. doi: 10.1093/ $\mathrm{aob} / \mathrm{mcq} 029$

White, P. J. (2012). "Ion uptake mechanisms of individual cells and roots: shortdistance transport," in Marschner"s Mineral Nutrition of Higher Plants, ed. P. Marschner (London: Academic Press).

White, P. J., and Hammond, J. P. (2008). "Phosphorus nutrition of terrestrial plants," in The Ecophysiology of Plant-Phosphorus Interactions, eds P. J. White and J. P. Hammond (Dordrecht: Springer). doi: 10.1007/978-1-4020-8435-5

Wiesler, F. (2012). Nutrition and Quality, 3rd Edn. Cambridge: Academic Press. doi: 10.1016/B978- 0-12-384905-2.00009-1

Wu, P., Shou, H., Xu, G., and Lian, X. (2013). Improvement of phosphorus efficiency in rice on the basis of understanding phosphate signaling and homeostasis. Curr. Opin. Plant Biol. 16, 205-212. doi: 10.1016/j.pbi.2013. 03.002

Xue, S. G., Chen, Y. X., Reeves, R. D., Baker, A. J. M., Lin, Q., and Fernando, D. (2004). Manganese uptake and accumulation by the hyperaccumulator plant Phytolacca acinosa Roxb . (Phytolaccaceae). Environ. Pollut. 131, 393-399. doi: 10.1016/j.envpol.2004.03.011

Yep, B., Gale, N. V., and Zheng, Y. (2020). Aquaponic and hydroponic solutions modulate $\mathrm{NaCl}$-induced stress in drug-type Cannabis sativa L. Front. Plant Sci. 11:1169. doi: $10.3389 /$ fpls.2020.01169 
Zhang, W., Li, X., Chen, F., and Lu, J. (2012). Accumulation and distribution characteristics for nitrogen, phosphorus and potassium in different cultivars of Petunia hybrida Vlim. Sci. Hortic. 141, 83-90. doi: 10.1016/j.scienta.2012. 04.010

Zhao, J., Davis, L. C., and Verpoorte, R. (2005). Elicitor signal transduction leading to production of plant secondary metabolites. Biotechnol. Adv. 23, 283-333. doi: 10.1016/j.biotechadv.2005.01.003

Zuardi, A. W. (2006). History of cannabis as a medicine: a review. Rev. Bras. Psiquiatr. 28, 153-157. doi: 10.1590/S1516-4446200600020 0015
Conflict of Interest: The authors declare that the research was conducted in the absence of any commercial or financial relationships that could be construed as a potential conflict of interest.

Copyright (c) 2021 Shiponi and Bernstein. This is an open-access article distributed under the terms of the Creative Commons Attribution License (CC BY). The use, distribution or reproduction in other forums is permitted, provided the original author(s) and the copyright owner(s) are credited and that the original publication in this journal is cited, in accordance with accepted academic practice. No use, distribution or reproduction is permitted which does not comply with these terms. 